\title{
Assessing Consumer Values and the Supply-Chain Market for the Integrated Water Heater/Dehumidifier
}

October 2004

Prepared by

B. G. Ashdown

G. D. Boudreau

M. V. Lapsa

M. J. Sherrod

Oak Ridge National Laboratory

M. Fields

Trevecca Nazarene University

C. St. John

D. Wurster

Clemson University 


\title{
DOCUMENT AVAILABILITY
}

Reports produced after January 1, 1996, are generally available free via the U.S. Department of Energy (DOE) Information Bridge:

Web site: http://www.osti.gov/bridge

Reports produced before January 1, 1996, may be purchased by members of the public from the following source:

\author{
National Technical Information Service \\ 5285 Port Royal Road \\ Springfield, VA 22161 \\ Telephone: 703-605-6000 (1-800-553-6847) \\ TDD: $703-487-4639$ \\ Fax: 703-605-6900 \\ E-mail: info@ntis.fedworld.gov \\ from the following source: \\ Office of Scientific and Technical Information \\ P.O. Box 62 \\ Oak Ridge, TN 37831 \\ Telephone: 865-576-8401 \\ Fax: 865-576-5728 \\ E-mail: reports@adonis.osti.gov \\ Web site: http://www.osti.gov/contact.html
}

Web site: http://www.ntis.gov/support/ordernowabout.htm

Reports are available to DOE employees, DOE contractors, Energy Technology Data Exchange (ETDE) representatives, and International Nuclear Information System (INIS) representatives

This report was prepared as an account of work sponsored by an agency of the United States Government. Neither the United States government nor any agency thereof, nor any of their employees, makes any warranty, express or implied, or assumes any legal liability or responsibility for the accuracy, completeness, or usefulness of any information, apparatus, product, or process disclosed, or represents that its use would not infringe privately owned rights. Reference herein to any specific commercial product, process, or service by trade name, trademark, manufacturer, or otherwise, does not necessarily constitute or imply its endorsement, recommendation, or favoring by the United States Government or any agency thereof. The views and opinions of authors expressed herein do not necessarily state or reflect those of the United States Government or any agency thereof. 
ORNL/TM-2004/159

\title{
ASSESSING CONSUMER VALUES AND THE SUPPLY-CHAIN MARKET FOR THE INTEGRATED WATER HEATER/DEHUMIDIFIER
}

\author{
B. G. Ashdown \\ G. D. Boudreau \\ M. V. Lapsa \\ M. J. Sherrod \\ Oak Ridge National Laboratory \\ M. Fields \\ Trevecca Nazarene University \\ C. St. John \\ D.Wurster \\ Clemson University
}

October 2004

Prepared by

OAK RIDGE NATIONAL LABORATORY

P.O. Box 2008

Oak Ridge, Tennessee 37831-6285

managed by

UT-Battelle, LLC

for the

U.S. DEPARTMENT OF ENERGY

under contract DE-AC05-00OR22725 


\section{CONTENTS}

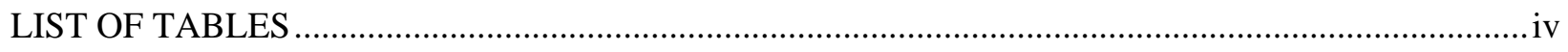

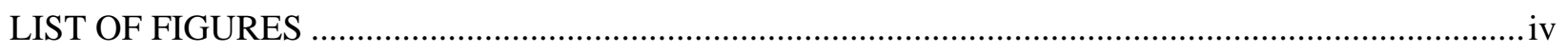

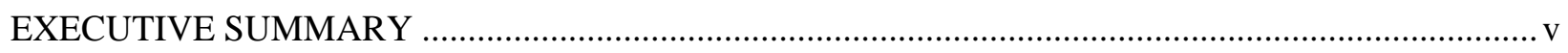

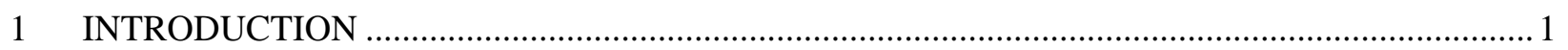

2 INTEGRATED WATER HEATER/DEHUMIDIFIER DEVELOPMENT ......................................... 2

2.1 OBJECTIVE AND PLAN OF ACTION........................................................................... 2

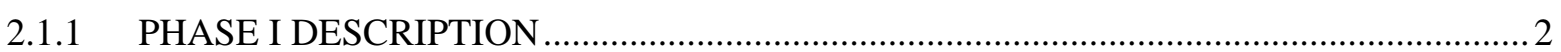

2.1.2 PHASE I ROLES AND RESPONSIBILITIES OF THE TEAM PARTNERS ..................... 2

3 INTEGRATED WATER HEATER/DEHUMIDIFIER PRODUCT OVERVIEW............................ 4

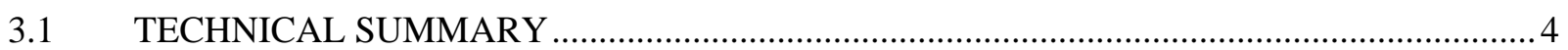

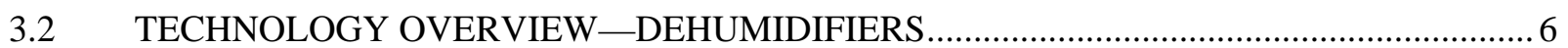

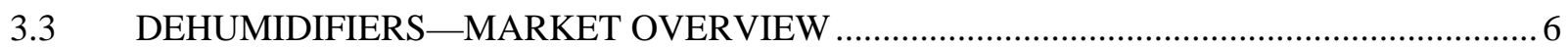

3.3.1 Household Humidity and Moisture Problems ...................................................................... 6

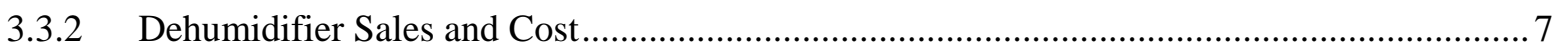

3.3.3 Dehumidifiers_Consumer Issues........................................................................................ 7

W.4 WATER HEATER TECHNOLOGY OVERVIEW ............................................................. 9

3.4.1 Residential Market Overview —Water Heaters .................................................................... 9

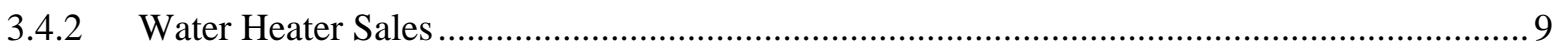

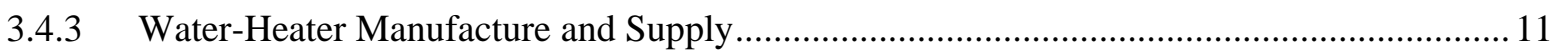

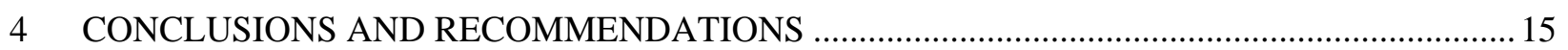

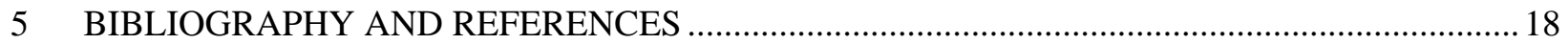

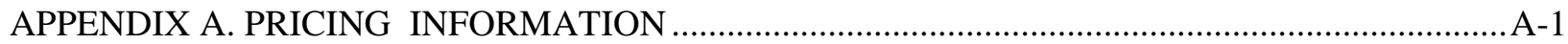

APPENDIX B. WATER HEATERS AND DEHUMIDIFIER MANUFACTURERS AND OTHER

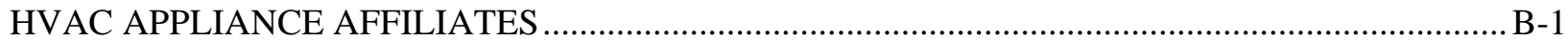

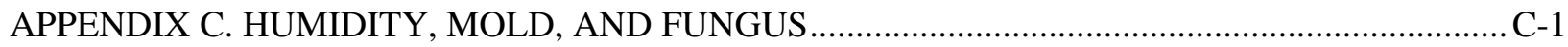

APPENDIX D. CONSUMER VALUES DISCUSSION RESULTS …............................................. 


\section{LIST OF TABLES}

Table 1. Dehumidification Selection Guide........................................................................................ 5

Table 2. Industry Shipments for Dehumidifiers................................................................................ 7

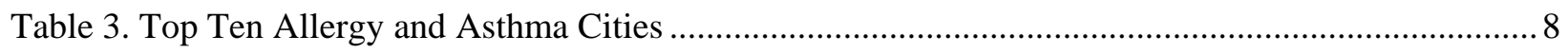

Table 4. 2001 Water Heater Manufacturer Market Shares by percentage of products produced ............... 12

\section{LIST OF FIGURES}

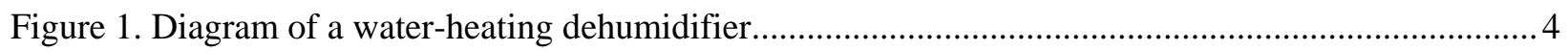

Figure 2. Photographs of early-phase integrated WHD prototypes at AB Tech 5

Figure 3. Dehumidifier selection guide 8 


\section{EXECUTIVE SUMMARY}

This paper presents a case study of the potential market for the dual-service residential integrated water heater/dehumidifier (WHD). Its principal purpose is to evaluate the extent to which this integrated appliance might penetrate the residential market sector, given current market trends, producer and consumer attributes, and technical parameters. The report's secondary purpose is to gather background information leading to a generic framework for conducting market analyses of technologies. This framework can be used to assess market readiness as well as factor preferred product attributes into the design to drive consumer demand for this product. This study also supports analysis for prototype design. A full market analysis for potential commercialization should be conducted after prototype development.

The integrated WHD is essentially a heat-pump water heater (HPWH) with components and controls that allow dedicated dehumidification. Adequate residential humidity control is a growing issue for newly constructed residential homes, which are insulated so well that mechanical ventilation may be necessary to meet fresh air requirements. Leveraging its successful experience with the energy-efficient design improvement for the residential HPWH, the Oak Ridge National Laboratory's (ORNL's) Engineering Science and Technology Division's (ESTD’s) Building Equipment Group designed a water-heating appliance that combines HPWH efficiency with dedicated dehumidification. This integrated appliance could be a low-cost solution for dehumidification and efficient electric water heating.

ORNL is partnering with Western Carolina University, Asheville-Buncombe Technical Community College, American Carolina Stamping Company, and Clemson University to develop this appliance and assess its market potential.

For practical purposes, consumers are indifferent to how water is heated but are very interested in product attributes such as initial first cost, operating cost, performance, serviceability, product size, and installation costs. The principal drivers for penetrating markets are demonstrating reliability, leveraging the dehumidification attributes of the integrated WHD, and creating programs that embrace first-cost and life-cycle cost principles.

There are some obstacles to successfully marketing this appliance:

- Many water heaters are installed in areas that would not benefit from either dehumidification or production of cool air, limiting the ability to market and price based on those additional attributes. For the dehumidification/cool-air attribute to be of value to consumers, the appliance should be located in an area needing dehumidification and/or cool air, such as a utility closet in the living space of the house or apartment or in an enclosed basement. If located in an unconditioned crawl space or garage, the dehumidification/cool-air attribute may be of limited value.

- When a water heater is installed as part of new construction, the builder/contractor chooses the model. Because they do not incur the cost savings or dehumidification benefits, there is little incentive to choose a system that costs more than a standard item.

- Usually, water heaters are replaced because they fail. Given the urgency of the situation, many homeowners will rely on a plumber to choose a model. The potential long-term cost savings and the dehumidification benefits would likely be less important than quickly replacing the water heater.

- Specialized installation or service may be required. Contractors are a key piece of the promotional puzzle for the adoption of energy-efficient technologies like integrated WHDs, and they must first be trained to properly install and service them. 
Situations that seem promising for integrated WHDs include:

- In highly humid areas of the country, particularly the Northwest (more subterranean units, moisture issues), the Northeast, the Southeast, and some coastal areas, installing this appliance in a utility closet, perhaps in a subterranean location of an apartment or house, would be advantageous if the promise of dehumidification were sufficient to motivate purchase of this integrated appliance.

- The reduction in humidity that the integrated WHD provides can curb or cancel the growth of mold. Mold, and the allergies that result from it, is a significant health issue in many parts of the country.

- Modification requirements resulting from the recent ANSI standard Z21.10.1-2001 (which applies to both natural gas and liquid propane units) may make gas water heaters more expensive and therefore a less attractive option than electric water heaters.

- Installing an integrated WHD in newly constructed, manufactured housing would be particularly beneficial to Energy Star ${ }^{\circledR}$ units where the overall energy savings for the home can offset some of the initial costs.

- Installing an integrated WHD in institutional laundry areas, such as those in apartment complexes, dormitories, hospitals, or assisted-living facilities, could provide relief from the humidity and heat generated by the washers and driers. Energy savings and cooler air would be additional benefits.

- Integrated WHDs can offset the high heat and humidity that plague specialized industrial situations where a localized source of hot water in an enclosed environment is necessary.

Factors that would facilitate marketing this integrated appliance include:

- There is some perceived value in the new technology; however, the value is not quantifiable until the energy savings and dehumidification levels are solidified. The investment costs and energy consumption of the integrated appliance should be compared to the costs and consumption of a traditional water heater plus a dehumidifier.

- As part of the feedback from discussions, we refer to the unit as an "integrated water heater/dehumidifier" since stakeholders and consumers were confused by the original name, "water heating dehumidifier."

- Integrated WHDs should be sold at a price close to that of existing technology — standard electric water heaters as well as dehumidifiers are priced relatively low.

- Energy savings and Energy Star ${ }^{\circledR}$ certification would facilitate this appliance’s marketability, especially with utilities and advocates.

- When their water heaters fail, homeowners make quick product-replacement decisions. Information on the new technology should be direct, easily accessible, and easy to understand (i.e., provides hot water, cools air in home, saves energy, incurs only a small increase in the initial cost, provides short payback, etc.).

To assess the market for the integrated WHD, ORNL and Clemson investigated several issues. Is there a market for this appliance? What would be the most attractive position for marketing it? Are there any problems or issues that might be associated with its use? Through preliminary discussions with representatives of relevant market segments, a target market was identified, and additional discussions were held in August 2004 with 15 representatives of 3 key target market audiences for the dehumidifying water heater:

- commercial building managers (hospitals, hotels, and an assisted living facility)

- plumbers (owners of local companies and plumbing departments of Lowe’s, Home Depot, and Sears)

- builders (builders of new residential home construction and a manufactured home builder) 
Most of the discussions revealed that the representatives did perceive value in the integrated appliance. The following key issues were identified for consideration by the technical design team and the market assessment team:

- The retail price of the end unit needs to be very cost competitive with existing standard electric water heaters.

- $\quad$ There will be strong competition with gas as the fuel source, as many new subdivisions are being designed for homes with gas.

- The end product will need to have a long warranty, be easy to install, and have clear instructions on whom to call for maintenance (plumber only).

- The noise level of the unit should be minimized.

- Building code requirements in target markets for the unit should be reviewed (i.e., managing drainage system).

- The size of the unit may be an issue in some locations (some closets in the southeast are 24 inches wide while the unit is projected to be 26 inches wide).

The residential and commercial target markets for the unit that were suggested by the 15 representatives are consistent with the market research conducted and documented in the report:

- markets in the Southeast, where the integrated appliance might help reduce the amount of air conditioning needed to keep homes cool;

- markets in the Northeast and Midwest, where basements are most common;

- markets in the Northwest, where humidity and mold/mildew issues are most prevalent; and

- $\quad$ the manufactured home market, where mold and mildew can be an issue.

The retail price, energy savings, dehumidification level, product name, and supply-chain entry for the new technology should be reviewed. Niche deployment opportunities for the integrated WHD, such as manufactured housing, commercial laundries, and assisted-living facilities, should be investigated, and partnerships with supply-chain stakeholders should be initiated.

To enhance the appliance's marketability, when the first prototypes are built and an estimated retail price is set, a small focus-group survey of consumers in the target-market should be conducted. A field trial demonstration program will also provide important feedback to the product design team. The market assessment team identified a new home builder, a contractor, and a distributor who are interested in participating in the field trial program for the integrated WHD. 


\section{INTRODUCTION}

Adequate residential humidity control is a growing issue for newly constructed residential homes, which are so well insulated that mechanical ventilation may be necessary to meet fresh-air requirements. Leveraging their successful experience with the energy-efficient design improvement for the residential heat-pump water heater (HPWH), the Oak Ridge National Laboratory (ORNL) Engineering Science and Technology Division's (ESTD’s) Building Equipment Group has designed a water-heating appliance that combines the efficiency of an HPWH with dedicated dehumidification. This dual service appliance, the integrated water heater/dehumidifier (WHD), is potentially a low-cost solution for both efficient electric water heating and dehumidification.

Partners for the integrated appliance's development are Western Carolina University (WCU), AshevilleBuncombe Technical Community College (AB Tech), American Carolina Stamping Company, Clemson University, and ORNL. Funds awarded to WCU from the Department of Energy's Office of Energy Efficiency and Renewable Energy through a competitive request for proposal will enable WCU and AB Tech to work with American Carolina Stamping to create a prototype of a new, dual-service, energyefficient water heater.

WCU and AB Tech faculty and students will take existing technology from Oak Ridge engineers and develop a new control system that combines elements of a home dehumidifier and water heater to achieve greater product reliability, flexibility of use, and energy savings.

Preliminary ORNL studies have shown energy savings near 50 percent when the system utilizes HPWH technology. The new project will build on the prior technology, adding dedicated dehumidification to attempt to reach Energy Star ${ }^{\circledR}$ ratings.

ORNL will conduct modeling and laboratory tests of several configurations to provide data to support the final design selection, which will lead to a marketable, low-cost, energy-efficient integrated WHD. Additional input to the design of the final product is being provided through a coordinated market assessment activity with Clemson University and ORNL.

By the end of CY 2004, two working prototypes will have been built by American Carolina Stamping Company and tested in an uncontrolled environment at AB Tech. Following a design-refinement phase, units will be tested under controlled conditions at ORNL. Work in CY 2005 is anticipated to include the construction of ten or more WHD packages for field-testing in North Carolina and Tennessee. 


\section{INTEGRATED WATER HEATER/DEHUMIDIFIER DEVELOPMENT}

Partners for the development of the initial prototype are WCU, AB Tech, American Carolina Stamping Company, Clemson University, and ORNL. The project overview is presented below.

\subsection{OBJECTIVE AND PLAN OF ACTION}

The project team is conducting a market assessment for input into the design of the initial prototype. The team's objective is to produce a marketable, low-cost, energy-efficient integrated appliance. The goal for this year (Phase I - May through December 2004) is to design, fabricate, and test two working integrated WHD prototypes that will meet Energy Star ${ }^{\circledR}$ performance standards. If the project is funded for a second year (Phase II - January through December 2005), ten units will be produced and field-tested, and a marketing plan for product commercialization will be developed.

\subsubsection{PHASE I DESCRIPTION}

During Phase I, the project team will accomplish the following:

- Pilot-test instrumentation methods on commercial water heater and dehumidifier units

- Design and prototype a control system for the integrated WHD

- Study design and engineering specifications for integrated WHDs

- Design documentation and preproduction drawings

- Fabricate preproduction integrated WHD prototypes

- Develop cost and scale-up plans for unit manufacture

- Test the prototypes

- Characterize the performance and efficiency of preproduction units

- Collect performance data on the units

- Analyze and report results of Phase I

\subsubsection{PHASE I ROLES AND RESPONSIBILITIES OF THE TEAM PARTNERS}

WCU will provide overall project coordination and management; support for integrated WHD instrumentation and controls, engineering documentation, and prototype construction; perform data analysis; and report results through a final report.

AB Tech will develop the pilot instrumentation site, install and validate testing instrumentation, identify and implement testing standards, develop test procedures, produce the integrated appliance's control system prototype, test the two prototype units, and archive the test data.

American Carolina Stamping will conduct the engineering and product design of the integrated appliance, provide engineering specifications, select components, fabricate two prototype units, deliver the units to the test site, and develop the cost and scale-up plan for further manufacture.

ORNL will conduct the marketing assessment (working with Clemson University) for the initial prototype design. ORNL will provide preliminary laboratory test data and assistance as needed regarding components modification and feasibility analysis on the condenser (standard, integrated, or hot rod), compressor (performance and configuration), fan and pump (construction), and control system design. The laboratory will also advise, refine and perform thermo-analysis on developed prototypes as necessary, and assist in developing the system-control logic. In addition, ORNL will supply marketing information and potential original equipment manufacturer (OEM) vendor contacts for prototype as 
needed, give input on technology direction, provide guidelines of the hot-water demand profile of the target consumer base, and assist with control-circuit design. 


\section{INTEGRATED WATER HEATER/DEHUMIDIFIER PRODUCT OVERVIEW}

This section will discuss the appliance's technical specifications and its potential for marketability. Because the integrated appliance incorporates water heater and dehumidifier technologies, this section also includes in-depth discussions on those appliances.

\subsection{TECHNICAL SUMMARY}

The integrated appliance prototype transfers the heat energy generated by the dehumidifier circuit into domestic water in a standard electric water heater tank. Energy savings result, as the electrical elements of the water heater will be active infrequently; therefore, most of the water heating will be done during the dehumidification/heat-pump cycle, which requires much less energy than the electrical resistance heating

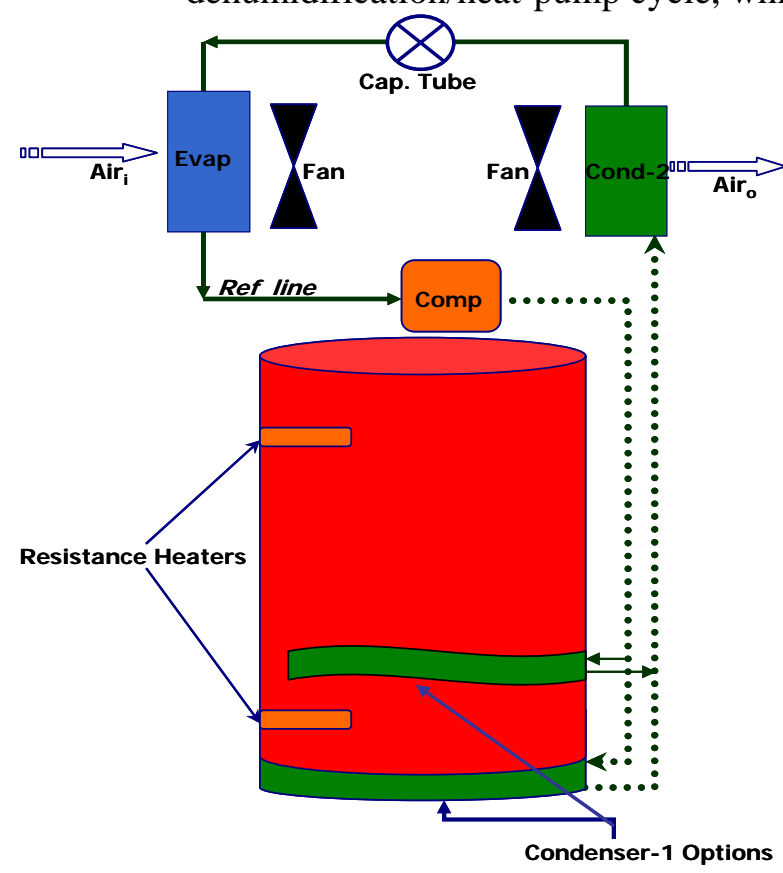

Fig. 1. Diagram of a waterheating dehumidifier. elements.

The integrated WHD is essentially an HPWH with components and controls that allow a dedicated dehumidification mode of operation. The initial design is a low-boy electric water heater approximately 56 inches high and 26 inches wide. HPWH technology is being incorporated into the water heater design with a goal of making the appliance $50 \%$ more efficient than a standard electric water heater. The dehumidification components will be located beneath the water heater. Installation is fairly simple in that, as with all electric water heaters, only a plumber is required.

As shown in Fig. 1, the device consists of a compressor, two condensers, an evaporator, and an expansion device. The aircooled condenser (condenser 2 at upper right of the figure) is needed to provide the dedicated dehumidification capability. There are several "condenser 1" (condenser 1 at lower right of figure) options that will be studied as part of this development effort: One is a submerged unit that provides enough surface area within the tank to heat the water, and the second is a surface-mounted heat exchanger attached to the tank bottom. If the submerged condenser option is selected, it will be installed near the bottom of the tank through the tank wall and doublewalled to meet safety requirements. This design option increases heat transfer from the refrigerant to the water and should increase the unit's performance. The second option (condenser externally attached to the bottom of the tank) is less intrusive, simpler to produce and, based on ORNL experience with wraparound condensers, should also perform well.

The design incorporates a drain-there will be no pan to empty, and the condensate will not be injected into the water tank. Dehumidifier capacity is usually measured in pints per 24 hours and is determined by two factors: the size of the space that needs to be dehumidified and the conditions that exist in the space before dehumidification. The efficiency of a dehumidifier is measured in liters of condensate per kilowatt hour under controlled conditions. This measure of performance is termed the Energy Factor (EF). The goal of the dehumidifier part of the appliance will be to reach Energy Star ${ }^{\circledR}$ compliance (having an Energy Factor of 1.2 or greater for a dehumidifier with the capacity to remove 20-50 pints of water from the air per day) with a 25- to 40-pint unit, capable of dehumidifying at least a $1000-\mathrm{ft}^{2}$ area over 24 hours. Figure 2 shows photographs of early-phase prototypes at AB Tech. 

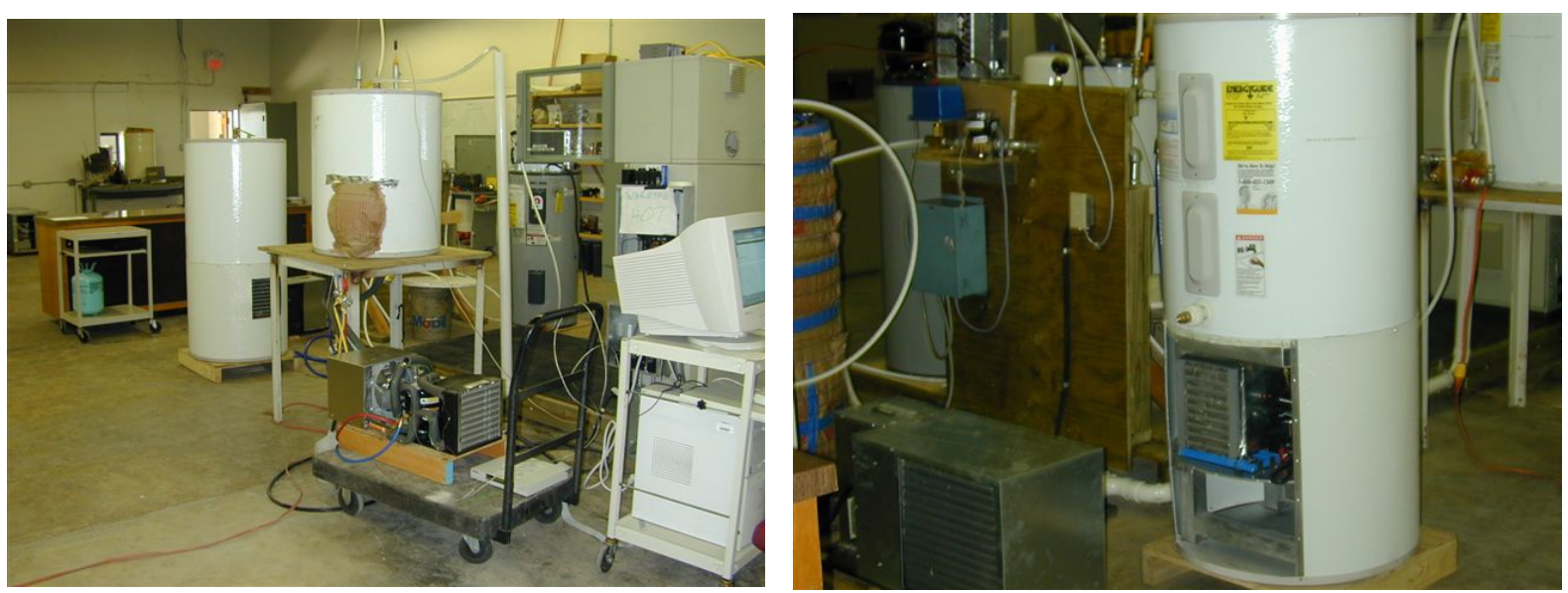

Fig. 2. Photographs of early-phase integrated WHD prototypes at AB Tech.

Table 1 allows estimation of the capacity necessary for dehumidification of a given area. (See the Energy Star ${ }^{\circledR}$ Northeast Website for a dehumidifier calculator at www.energystar.gov/index.cfm?c=dehumid.pr_basics_dehumidifiers\#capacity.)

\begin{tabular}{|c|c|c|c|c|c|}
\hline Table 1. Dehumidification & Sele & ction $\mathrm{C}$ & uide & & \\
\hline $\begin{array}{r}\text { Values indicate dehumidification requi } \\
\text { based on area of space to be dehumid } \\
\text { conditions }\end{array}$ & $\begin{array}{l}\text { ired in } \\
\text { lified } a\end{array}$ & $\begin{array}{l}\text { pints } p \epsilon \\
\text { nd pre-c }\end{array}$ & $\begin{array}{l}\text { r } 24 \text { hol } \\
\text { lehumid }\end{array}$ & $\begin{array}{l}\text { urs, } \\
\text { ified }\end{array}$ & \\
\hline $\begin{array}{l}\text { Air comfort level of the living space } \\
\text { before dehumidifying }\end{array}$ & & Area & in Squa & are Fee & \\
\hline & 500 & 1000 & 1500 & 2000 & 2500 \\
\hline $\begin{array}{l}\text { Moderately damp-space feels damp and has } \\
\text { musty odor only in humid weather }\end{array}$ & 10 & 14 & 18 & 22 & 26 \\
\hline $\begin{array}{l}\text { Very damp-Space always feels damp and } \\
\text { has musty odor. Damp spots show on walls } \\
\text { and floor }\end{array}$ & 12 & 17 & 22 & 27 & 32 \\
\hline $\begin{array}{l}\text { Wet-Space feels and smells wet. Walls or } \\
\text { floor sweat, or seepage is present }\end{array}$ & 14 & 20 & 26 & 32 & 38 \\
\hline $\begin{array}{l}\text { Extremely wet-Laundry drying, wet floor, } \\
\text { high load conditions }\end{array}$ & 16 & 23 & 30 & 37 & 44 \\
\hline
\end{tabular}

The retail price for an integrated WHD is estimated to be between $\$ 400-\$ 600$. For $1600 \mathrm{ft}^{2}$, a dehumidifier should remove about 30 pints of water collected over a 24-hour period. A 30-pint dehumidifier costs about \$160; a 65-pint dehumidifier costs about $\$ 250$. The estimated retail price for standard 40- to 50-gal electric water heater is around \$200 or \$300. Appendix A contains price comparison information on the integrated appliance and standard electric water heaters and dehumidifiers. 


\subsection{TECHNOLOGY OVERVIEW-DEHUMIDIFIERS}

Dehumidifiers are relatively small machines - about a foot or two high and a foot wide - that reduce the level of moisture in the air. Dehumidifiers use refrigeration principles to cool metal coils. When damp air is blown over cold coils, water condenses rapidly onto the coil and is drained away into a tank. A humidifier is controlled by an adjustable humidistat located in the inlet air stream.

The moisture removal rate depends on several factors. Most importantly, the room temperature determines the minimum humidity level. With most dehumidifiers the air comes out at around 30 percent relative humidity. At $70^{\circ} \mathrm{F}$ and higher it is possible to reduce the room humidity to 35 to 40 percent. As the temperature goes below $70^{\circ} \mathrm{F}$ and down into the 50s, this will rise to 60 percent.

Other factors affecting moisture removal are the size of the area being dehumidified, construction of the room, and the climate based on location.

Several companies are developing new dehumidification technologies. These include a technology to accommodate dew point temperatures down to $26^{\circ} \mathrm{F}$ using direct expansion cooling, whole-house dehumidifiers with a 90-pint-per-day capacity that can be installed almost anywhere and that have automatic control, hot-gas reheat dehumidification systems, and disinfecting dehumidification systems.

\subsection{DEHUMIDIFIERS-MARKET OVERVIEW}

\subsubsection{Household Humidity and Moisture Problems}

Although too-dry air is common in older, less energy-efficient homes, the reverse is true with a tight, more energy-efficient modern home. The reduced free exchange of air can cause high indoor humidity. Damage to wood floors and electronic equipment, increased dust, respiratory problems, throat and skin irritation, rot, pests, mold and mildew, dust mites and allergies are other common problems that result from indoor humidity levels that are either too low or too high.

Excess humidity can produce enough condensation to stain ceilings and walls and cause flaking paint and peeling wallpaper. In warmer climates, the combination of high humidity and heat provides the optimal environment for pests and mold (USA Today 2004).

In the United States, more than 60 percent of basement homes have moisture problems (www.thisoldhouse.com/toh/html/almanac/almanac_030304_march.html). In 1995, 39 percent of new homes had a full or partial basement, unchanged from 1994. But, the presence of basements in homes varies widely from region to region. Just 17 percent of new homes built last year in the South and 21 percent in the West included a basement, compared to 86 percent in the Northeast and 79 percent in the Midwest (Picket Fence Preview, Inc. 1997). Slab-on-grade is frequently used in earthquake zones of the United States, but this form of foundation is not the only choice in such areas, according to sources within the industry. On the West coast, however, basement homes are the exception, not the rule. Instead of basements, homes with three and even four-car garages are popular (D. Amaruso, http://www.newhomesource.com/market/articles/newhomesecho.htm.)

Homeowners expect basements in the Northeast, but this is a fading trend, says Dennis Gottstein, a community builder with K. Hovanian Enterprises, Inc., a New Jersey firm that constructs and markets single-family homes, townhouses, and condominiums in planned residential communities throughout the United States. "People have perceived that basements are better than slab-on-grade foundations, but there is no real difference in the home's stability,” adds Gottstein. NewHomeSource.com, S. Kasarik 2004). 


\subsubsection{Dehumidifier Sales and Cost}

Dehumidifiers, along with disposers and compactors, made up 3 percent of 2001 U.S. appliance sales (AHAM 2002). Dehumidification sales went up significantly from 2002 to 2003 and are projected to increase again in 2005 (see Table 2). Nearly 38 percent of dehumidifiers sold in the United States will be in the northeast quadrant of the country (Detroit Free Press News 2001). Dehumidifiers are considered seasonal products. The past summer was wet in primary markets, which was great for dehumidifier sales. In 2003, a 30-pint unit cost about \$160; a 65-pint unit, in the mid-\$200 range. Most units are only used 3 to 4 months of the year, and last 10 to 12 years. In 2004, prices for dehumidifiers went down (\$179 and \$199; 30- and 65-pint units, respectively) (Air

Table 2. I ndustry Shipments for Dehumidifiers (Thousands of Units)

\begin{tabular}{rrrrrrr}
\hline 1999 & 2000 & 2001 & 2002 & 2003 & 2004 & 2005 \\
\hline 950 & 975 & 806 & 799 & 1,311 & 1,280 & 1,325
\end{tabular}

Source: AHAM 2004. Conditioning, Heating \& Refrigeration News, 2004). Dehumidifiers far exceeded shipment records in 2003 and will probably face substantial declines in 2004 (unless summer temperatures are unusually high). AHAM's last forecast (see Table 2), published in November, anticipated manufacturers' unit shipments of dehumidifiers in 2004 would decline 10.7 percent for dehumidifiers. Appendix B lists major manufacturers of dehumidifiers.

\subsubsection{Dehumidifiers-Consumer Issues}

Dampness in buildings is a concern because it often leads to growth of molds and bacteria and to increased emissions of chemicals from building materials. In addition, dampness causes structural degradation of buildings (LBNL 2004). Besides helping to make a home more comfortable and the air cleaner, dehumidifiers can help combat the problems that accompany high indoor humidity, helping to protect the investment of one's home. Not only can dehumidifiers reduce damage from high humidity (to wood, paint, electronic equipment), they also offer health benefits by reducing mold and mildew, thereby reducing allergies and irritations.

Health. A moist environment encourages mold, which is a major cause of illness (primarily allergies) in the United States (see Appendix C for a discussion on humidity, mold, and fungus). Using a dehumidifier can inhibit or prevent the growth of mold. A recent National Academy of Sciences study report (LBNL 2004) reports that "there is robust scientific evidence of an association of increases in selected respiratory health effects with building dampness or visible mold.” A wide variety of symptoms have been attributed to the toxic effects of different molds. The medical problems may be caused by toxic gases produced by the molds or by reactions to the mold particles themselves. Commonly reported symptoms include runny noses, eye irritation, congestion, aggravation of asthma, headaches, dizziness, and fatigue. More severe symptoms may include reports of profusely bloody runny noses, the coughing up of blood, severe headaches, fibrous growth in the lungs and at least in one reported instance-cognitive dysfunction and loss of memory. There is no practical way to eliminate all molds and mold spores in the indoor environment; the way to control indoor mold growth is to control moisture. (Claims Magazine 2000).

Table 3 lists the top ten U.S. “allergy cities” and “asthma cities,” many of which are in the Southeast. Given its high humidity and mold levels, this region of the country could benefit from the integrated WHD. In addition to the Southeast, other areas of the country could benefit from the integrated WHD as well. Maps depicting sunshine hours, precipitation, and mean relative humidity (see Appendix D) support residential and commercial target markets for dehumidification in parts of the Northeast, Midwest, and Northwest. Most of the representatives with whom we discussed the integrated WHD's potential suggested these areas as having market potential.

A dehumidifier is rated for the size of and the conditions in the space it will dehumidify. Picking the wrong one can be costly in terms of both money and property. Figure 3 illustrates the different sizes needed for different levels of moisture and areas of space. Some experts recommend going with a large model. If too small a unit is used, it will operate continuously and probably not dehumidify down to 50 


\begin{tabular}{|c|c|}
\hline \multicolumn{2}{|c|}{$\begin{array}{l}\text { Table 3. Top Ten Allergy and Asthma Cities } \\
\text { (allergy city/ asthma city) }\end{array}$} \\
\hline $\begin{array}{l}\text { 1. Austin-San Marcos, TXI } \\
\text { Knoxville, TN }\end{array}$ & $\begin{array}{l}\text { 6. Milwaukee-Waukesha, WI/ } \\
\text { Memphis, TN }\end{array}$ \\
\hline $\begin{array}{l}\text { 2. Knoxville, TN/ } \\
\text { Little Rock, AR }\end{array}$ & $\begin{array}{l}\text { 7. Des Moines, IA/ } \\
\text { Toledo, } \mathrm{OH}\end{array}$ \\
\hline $\begin{array}{l}\text { 3. Memphis, TN/ } \\
\text { St. Louis, MO }\end{array}$ & $\begin{array}{l}\text { 8. Dallas-Ft. Worth, TX/ } \\
\text { Kansas City, MO-KS }\end{array}$ \\
\hline $\begin{array}{l}\text { 4. Kansas City, MO-KS/ } \\
\text { Madison, WI }\end{array}$ & $\begin{array}{l}\text { 9. Columbus, OH/ } \\
\text { Nashville, TN }\end{array}$ \\
\hline $\begin{array}{l}\text { 5. Tulsa, OK/ } \\
\text { Louisville, KY }\end{array}$ & $\begin{array}{l}\text { 10. Oklahoma City, OK/ } \\
\text { Hartford, CT }\end{array}$ \\
\hline
\end{tabular}

Source: Allergy and Asthma Foundation of America

percent, the level at which mold will not grow. A larger unit will shut off more quickly and is less likely to overflow (Allergy Consumer Review Issue 65, B. Cobe).

Sizing rule of thumb for most areas except coastal (where the square foot coverage will be reduced as much as 50 percent) is:

- Up to 400 square feet: 25 or 30 pint

- Up to 800 square feet: 40 pint

- Up to 1000 square feet: 50 pint

- Up to 1300 square feet: 65 pint

All of these figures are based on an 8-ft-high ceiling. If the height is $10 \mathrm{ft}, 25$ percent more should be added to the square footage; if $12 \mathrm{ft}$, then add 50 percent, etc. (Allergy Consumer Review Issue 65, B. Cobe).

A couple of disadvantages to dehumidifiers is that they can be expensive to run and noisy; however, the biggest complaint about them is that they must be emptied all the time. An automatic shutoff feature when the pan is full can help avoid problems of water overflowing or repeated checks on the water level; however, with this feature, the unit

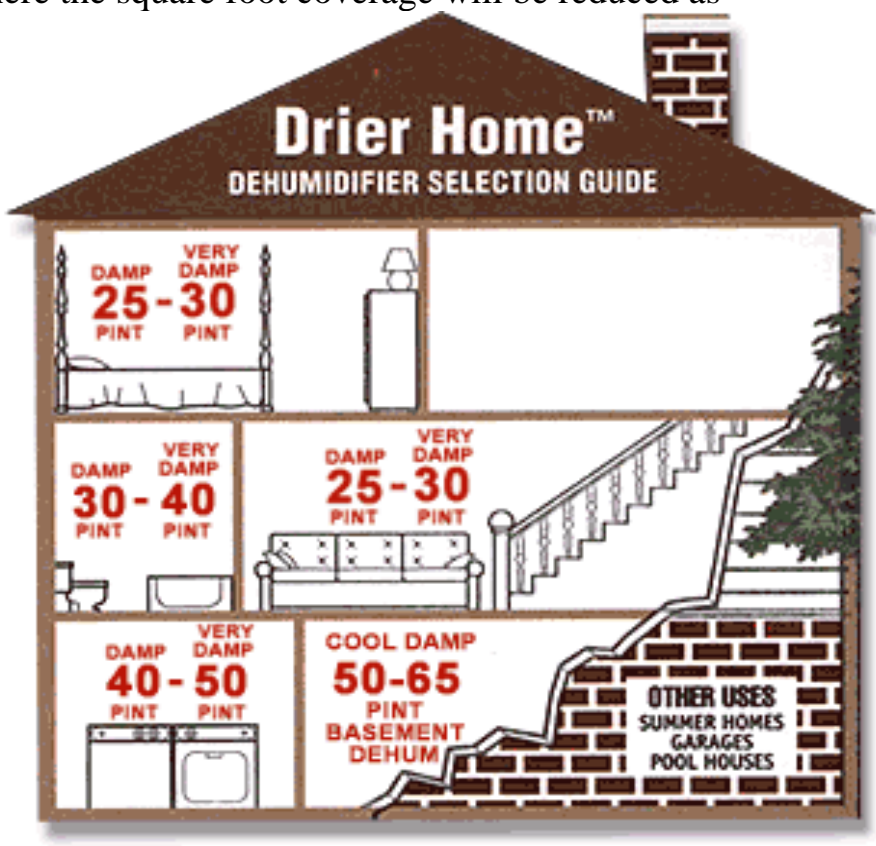

Fig. 3 Dehumidifier selection guide. Source: allergybuyersclub.com. stops running until the pan is emptied. Most manufacturers make the units so a hose can be attached and run into a drain, keeping the unit running continuously. (Air Conditioning, Heating \& Refrigeration News 2004.) The machines also shut off if the temperature falls too low (around $65^{\circ} \mathrm{F}$ ). The dehumidifier will remain off until the frozen coils thaw. (Whirlpool is patenting a technology to warm the coils if they get too cold. This new technology will be able to keep a dehumidifier working down to $50^{\circ} \mathrm{F}$.)

Energy consumption. Fans and dehumidifiers use less energy than air conditioners and can help to make the home more comfortable during the warm months (NAHB Research Center 2004). But dehumidifiers 
consume as much electricity as the average refrigerator and cost U.S. consumers approximately one billion dollars a year in utility bills (Energy Star 2004). Using an integrated WHD, which uses less than 50 percent of the electricity of a standard electric water heater, would in some cases eliminate the need for a dehumidifier and save the consumer money by avoiding the need to purchase another appliance and saving energy.

According to Aprilaire, a manufacturer of dehumidifiers, "Homes are being built tighter and are more energy efficient due to improvements in insulation, air and vapor barriers, windows and caulking, and product application. Unfortunately, this has also led to reduced air infiltration rates and increased relative humidity.” (Air Conditioning, Heating \& Refrigeration News 2004.) Subsequently, integrated appliances such as the integrated WHD could be more advantageous for tighter homes.

\subsection{WATER HEATER TECHNOLOGY OVERVIEW}

\subsubsection{Residential Market Overview - Water Heaters}

Water heating accounts for 20 percent or more of an average U.S. household's annual energy costs. By the year 2000, there were more than 115 million units of housing in the United States, including slightly fewer than 2 million new home completions during the year. The majority of U.S. single-family residences are built by small firms (sole proprietorships and business with 1-4 employees) and mediumsized firms (5-19 employees). In 1997, there were about 470,000 single-family homebuilding firms in the United States. About 70 percent of these firms were sole-proprietor operations accounting for 15 percent of the nation's annual construction by dollar value. Ninety-three percent of U.S. home-building firms had fewer than four employees. At the turn of the past century, there were, however, some large firms in the industry. While only 1 percent of firms had more than 20 employees in 1997, these larger firms accounted for 32 percent of annual receipts.

Replacement is by far the largest revenue earner in the residential and commercial water heater segments, outdoing new installments in new construction. Full replacement is the fastest, easiest, and most economical solution for replacing old tanks. Hard water, high temperatures, and very frequent refilling cycles also accelerate deterioration of tank parts.

Most homes today have twice as many fixtures as they did 30 years ago, and hot water must travel further, in piping with a larger diameter than in the past, to get to its destination (Reeves Journal 2004). Luxury technologies with collateral positive health benefits such as hydronic home heating are gaining popularity. These products require significantly more hot water than the average tank-type home water heater produces. Houses are also increasing in size, with bathrooms offering whirlpool baths and multiple shower nozzles within a single shower enclosure. These gradually evolving consumer demands are pressuring traditional tank manufacturers to provide water heaters that increase the quantity of hot-water supply while being cost effective (Frost \& Sullivan 2003).

\subsubsection{Water Heater Sales}

The Gas Appliance Manufacturer's Association (GAMA) lists annual sales of more than 4.9 million gas-fired heaters (4.6 million natural gasfired) and 4.3 million residential electric water heaters in 2001, with the U.S. market growing gradually from 4.2 million gas-fired and 3.8 million electric units shipped from manufacturers in 1992 (GAMA 2003). Other types of water heaters on the market include oil-fired and solarpowered appliances as well as desuperheater, geothermal heating and cooling systems, and multi-function water heating systems. Demand or tankless water heaters, also called instantaneous

\begin{tabular}{|c|c|c|c|}
\hline \multicolumn{4}{|c|}{$\begin{array}{l}\text { Residential Electric Water Heaters- } \\
\text { Shinmentc }\end{array}$} \\
\hline Quarter & 2002 & 2003 & 2004 \\
\hline 1 & 1169.2 & 1133.0 & 1159.1 \\
\hline 2 & 1040.3 & 1037.8 & 1055.4 \\
\hline 3 & 1044.5 & 1039.2 & 1081.8 \\
\hline 4 & 1136.5 & 1215.0 & 1189.4 \\
\hline & 4390.5 & 4425 & 4485.7 \\
\hline
\end{tabular}

For 2003, a 0.8 percent increase to 4.425 million units; for 2004, a 1.4 percent increase to 4.486 million units

Data source: GAMA 2003

Forecast source: Delano Data Insights 
or booster heaters, are also sold in both gas-fired and electric models, notably to residences with limited space like apartments or mobile homes. Hybrid systems may combine two different water-heating technologies. Multi-function heating systems include hydronic systems that use tubing to pass heated liquids to locations around the home. The GAMA April 2003 Consumers Directory lists 20 brand-name residential water heaters, covering natural gas and propane-fired models, electric and oil-fired water heaters, heat-pump water heaters, and combination water heaters and space heaters.

\subsubsection{The "Gas versus Electric" Issue}

More than half of U.S. electric water heaters are in the South, and the South still has more electric water heaters than gas water heaters. In all other regions, gas dominates. The Northeast has more than twice as many gas water heaters as it has electric (see data below) (EIA 2001). Obviously, the integrated appliance faces competition in the gas water heater market.

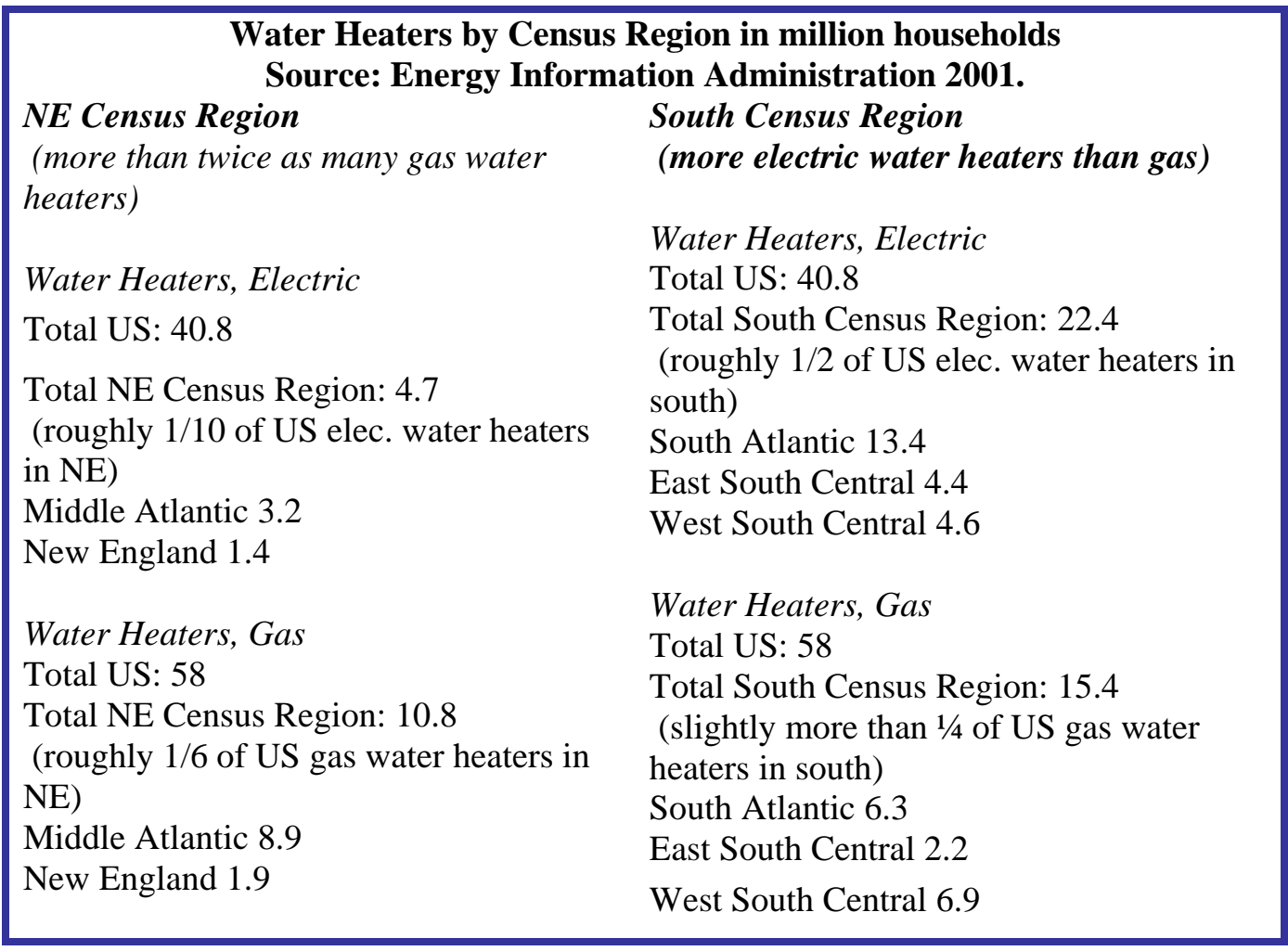

Effective July 1, 2003, residential gas-fired water heaters with storage capacities of 30, 40, or 50 gallons must meet ANSI standard Z21.10.1-2001, which applies to both natural gas and liquid propane units. Their design "shall not ignite flammable vapors outside the water heater created by the spilling of...gasoline onto the floor.” Any conventional, atmospheric-type water heater with a storage capacity of 50 gallons or less produced on or after the effective date must be designed according to the ANSI standard. This industry-wide change will increase the price of gas water heaters, perhaps significantly (ANSI 2001).

The competition of electric with gas water heaters is an important factor for consideration in developing new electric water heating technologies. Other key market factors for electric water heaters include:

- Nationally, electric water heaters account for about 45 percent of the residential market (roughly 16 billion kWh annually).

- Electric water heaters are losing market share to gas at a national rate of approximately 4 percent per year. 
- An electric water heater represents about 30 percent of the energy used in a home-4000 to 5000 $\mathrm{kWh} /$ year.

- Collectively, electric water heaters contribute between 20 to 25 percent of their connected load to peak (.8 to $1.0 \mathrm{~kW})$

- The kilowatt-hour sales during peak times and at peak margins make up most of the revenue from water heating (http://www.vaughncorp.com/tkbusinessop.html).

\subsubsection{Market Growth}

Conventional, residential-size storage water heaters are manufactured and distributed under an extremely cost-competitive market regime where factory costs have been reduced to minimal levels and profit margins and distribution markups are very thin. The cost of the insulated storage tank is the major part of the factory cost; the heat source (i.e., the resistance heating elements and thermostats or the gas burner and gas control valve) only accounts for about 10 percent of the manufacturing cost.

Standard electric and natural gas water heaters are sold with very small markups. The high efficiency types tend to be discounted less; customers pay a premium for the higher efficiency and longer warranty. The generally low profitability of the water heater business (as a result of the aforementioned low markups) is often cited as a reason that conventional water heater manufacturers have not pursued higherefficiency products.

According to a report by the market research firm Frost \& Sullivan, "US Hot Water Heating Equipment Markets," the total market rose from $\$ 1.94$ billion in 1998 to $\$ 1.99$ billion in 1999 . The growth rate is expected to remain steady through 2006. The report identifies three primary sectors for the U.S. water heater market: standard tank-type, emerging tankless, and copper-finned boilers.

Shipments of residential gas water heaters in 2003 are up near 20 percent over last year, according to GAMA. The increase, Mr. Gaddis says, could be due to manufacturers moving the last of their gas-fired inventory that do not have the flammable vapor resistant factor (FVIR) feature (see further discussion under 3.4.3.5, The Impacts of Mandates) and those that would not meet next year's federal efficiency standard. Residential electric water heater shipments were off in first quarter 2003, but rebounded in the second quarter. The total for the two quarters is slightly lower than the same period last year.

\subsubsection{Water-Heater Manufacture and Supply}

The residential water heater market is dominated by a small number of manufacturers, all of whom sell both residential- and commercial-sized storage water heaters, including electric-resistance immersion, and natural-gas- and propane-fired models. The most frequently used gas-fired water heater is a tank-based 40-gallon model. Electric water heaters are most often of the 50-gallon tank-based type. The five largest manufacturers of residential models are Rheem Manufacturing, American Water Heater Company, A. O. Smith, Bradford White, and State Industries; all make both gas-fired and electric models (Cooper et al. 1997, PNNL 1995).

- $\quad$ Rheem is a leading North American producer of water heaters, central warm air furnaces and air conditioners, and swimming pool heaters and commercial boilers. The company's products are used for residential and commercial applications and operate on a variety of fuels. Rheem is headquartered in New York, with manufacturing facilities in Montgomery, Alabama; Fort Smith, Arkansas; Milledgeville, Georgia; and Oxnard, California. Rheem has two Canadian locations in Hamilton, Ontario and Mississauga, Ontario, and one Australian location in Mulgrave, Victoria. Rheem also has a manufacturing facility located in Nuevo Laredo, Mexico. All manufacturing facilities are ISO 9000 certified. In 1987, Rheem became a wholly owned subsidiary of Paloma Industries of Nagoya, Japan, the world's largest producer of gas appliances. http://www.rheem.com

- American Water Heater Company, with more than 1,000 employees, is located in Johnson City, Tennessee. GSW, Inc., of Oakville, Ontario, purchased American Water Heater Company in 2002. 
American Water Heater Company is a leading manufacturer of high-quality water heater products. With manufacturing, research and development, and corporate offices located in Johnson City, Tennessee, American offers a comprehensive line of residential and commercial water heaters. The company's Tennessee home is an ideal location to serve America's largest population centers. From its Tennessee warehouse, American products can be delivered to almost any location within North America in a matter of days. With modern manufacturing and warehouse facilities and more than 1,000 employees, American can produce thousands of water heaters each day.

- A. O. Smith Corporation has facilities in Canada, England, Ireland, Hungary, the Netherlands, and China and employs approximately 17,000 people. A. O. Smith has acquired State Industries, which held 18 percent of the market in water heater sales, and recently announced plans to consolidate the North American manufacture of residential water heaters at its Ashland City, Tennessee, and Juarez, Mexico, facilities (http://www.hotwater.com/).

- Bradford White Corporation manufactures water heaters in Middleville, Michigan. With a long and successful history dating back to 1881 Bradford White today is one of the most technologically advanced water heater manufacturers in the world. With headquarters in suburban Philadelphia and its manufacturing operation in Middleville, Michigan the company builds all of its products strictly for wholesale distribution. Bradford White water heaters for residential, commercial and hydronic space heating applications are designed to be installed by plumbing and heating professionals. (http://www.bradfordwhite.com/)

Of the approximately 9 million annual sales, 4.2 million go through plumbing wholesalers to plumbers and contractors (1.2 million of these are for new construction). About 4.7 million go to large retail homesupply outlets where they are purchased by plumbers or homeowners. Relatively small numbers go to mobile home manufacturers ( 0.2 million) or export (0.2 million).

Table 4. 2001 Water Heater Manufacturer Market Shares by percentage of products produced (Source: Appliance Magazine 2002)

\begin{tabular}{lcc}
\multicolumn{1}{c}{ Company } & $\begin{array}{c}\text { Market } \\
\text { Share } \\
\text { (percent) }\end{array}$ & $\begin{array}{c}\text { Total Units } \\
\text { Shipped }\end{array}$ \\
\hline Rheem Manufacturing & 41 & 3798438 \\
State Industries* & 18 & 1667607 \\
American Water Heater & 14 & 1297028 \\
Bradford-White & 14 & 1297028 \\
A.O. Smith & 13 & 1204383 \\
\hline & & $9,264,484$ \\
\hline
\end{tabular}

A.O. Smith has since acquired State Industries.

\subsubsection{Distribution Channels}

Each of these manufacturers has a number of parts suppliers to deal with. However, of more interest to the current project effort is the relationship between these manufacturers and their immediate customers. The two major distribution channels for manufacturers of water heaters are plumbing wholesalers (such as Ferguson, Noland, and Apex) and large retailers (such as Home Depot, Lowes, Menards, and Sears) with total manufacturers' sales divided approximately equally between wholesale and retail buyers (although some manufacturers prefer to deal only with wholesalers). Plumbing firms and other contractors who install water heaters get their units primarily from these two sources, as do homebuilders who do not go through a contractor. An NREL-sponsored survey of 84 larger builders (producing at least 100 homes annually in southern California, Phoenix, Las Vegas, and Florida) (GAMA 2003) found that 82 percent purchased conventional water heaters from the installing contractor/subcontractor. Only 6 percent purchased units directly from the manufacturer, and only 7 percent were purchased from a wholesale distributor (and 2 percent from “other"). Some 84 percent of the 31 distributors and subcontractors interviewed purchased their water heater units directly from the manufacturer (GAMA 2003), selling 77 
percent of the time to a builder, 38 percent of the time to another contractor or hybrid distributor/installer, 6 percent of the time to a retailer, and 16 percent of the time to "other" customers including wholesalers and homeowners.

\subsubsection{Transportation}

Trucking seems to be the only mode of transport used throughout the supply chain. From the manufacturing sites or their regional warehouses, water heater units are shipped to a much larger number of retail and wholesale outlets. This appears to occur via a set of regionally located warehouse/distribution centers operated (or leased) by a manufacturer. The number of these warehousing sites could be obtained from each manufacturer. From these distribution centers the manufacturer delivers units to a much larger number of local or regionally located retailers and plumbing contractors, as well as to some builders. The number of wholesale plumbing establishments was not readily available. As an example, the Apex Supply Company, with headquarters in Atlanta, Georgia, sells water heaters made by a number of manufacturers out of 23 locations around the southeastern United States. The geographic coverage of the larger retail companies, such as Home Depot, Lowes, and Sears, is clearly more extensive.

\subsubsection{Utilities}

Some utilities, including a number of regional energy-supply cooperatives, also sell specific energyefficient units to homeowners and/or plumbing contractors/water-heater installers. These sales are often subsidized, providing additional profit to the installer and (through agreement with the installer) to the homeowner. How and/or where these utilities obtain their supply of water heaters was unclear. One utility indicated that it helped homeowners find installers. Direct purchases from and delivery by the manufacturer might be one way to cut down supply-chain costs. How utilities acquire water heaters was also unclear. It also appears that these plumbing wholesalers/distributors are responsible for delivering their water heaters to the building sites or contractor locations by truck. A large builder might order a truckload of units for delivery to a building site. However, this implies that numerous units can easily be stored by the builder or are all being put into houses in short order. A more common situation could be for one or more units to be delivered to a specific location, implying less-than-truckload transport. One would expect storage of water heaters to be pushed back up the supply chain to the extent possible, i.e., just-intime delivery may now be the norm, as in some other manufacturing supply chains.

\subsubsection{Supply-Chain Processes}

Key processes in supply chains include informational and financial as well as physical interactions or transfers between participants. In the National Renewable Energy Laboratory's (NREL's) 1999 study of the market for solar water heaters, it was found that direct, personal selling to builders by installation contractors was the major and most successful (59 percent) method of communication, with trade shows second, followed by trade advertising (NREL 1999). Manufacturer-based model homes programs, design centers, incentives, or discounts were also popular promotions with builders. Builders in turn referenced presentations by new-home-sales agents, manufacturers' brochures, and model-home point-of-purchase displays as their top three methods of marketing to homebuyers. This same study (NREL 1999) also quotes a 1998 survey of 600 large builders (builders with annual sales of more than 100 units). Eightythree percent of these builders used model homes to sell to homeowners in their communities. In choosing a specific energy-efficient product, builders in the NREL study cited their cost/profit, local code requirements, and level of consumer demand as their three main concerns. Two other 1998 surveys of builders are also cited in which supply-chain cost savings are seen as a key consideration.

Supply-Chain Management and Integration. The profit margin on the manufacture of individual waterheater units is quite small (Cooper et al.), with heavy discounts on sales by retailers and wholesalers, who make up some of this through ancillary parts sales. The units must also be able to handle postmanufactured markups at each stage in the supply chain and notably at the point of installation. This means that new products seeking to enter the market must compete with a well-established and highly competitive industry that has been working to keep down its logistical costs. According to Cooper et al., "selling, general and administrative costs (including indirect labor, promotion, commissions, and 
transportation) in the appliance industry (not the water heater industry per se) are around 16 percent, compared to about 6 percent profit.

One way to reduce costs would be to better manage, and where possible, integrate, the supply chain. A form of supply-chain integration seems to be taking place in the case of Apex Supply Company (see previous page), a Home Depot-owned company and a wholesale distributor of plumbing and other supplies. Both Home Depot and Lowes deliver and install water heaters in homes.

Rheem has established a nationwide network of warehouses to meet demands for quick delivery. The company uses seven USCO Logistics facilities across the United States. Rather than stock every model unit, USCO facilities store just several basic model types that can be customized at the warehouse. Each USCO facility can custom-configure each electric water heater by changing heating elements and the voltage and wattage to conform to the specific unit ordered. After configuring the product, USCO then labels water heaters with the appropriate model and serial number information based on the customer order. This mass customization strategy has apparently reduced Rheem's inventory carrying costs by 10 percent. USCO Logistics is a full-service provider of globally integrated logistics solutions supported by sophisticated information systems. Rheem also uses United Supply and Distributing Company's (Rheem Supply) three warehouses in Maryland and Virginia for distributing its water heaters.

In addition to the larger wholesale and retail enterprises that dominate the physical distribution chain, small-scale distributors represent about 5 percent of the water heater market, supplying to both wholesalers and retailers, as well as occasionally to builders and contractors (i.e., installers). Controlled Energy Corporation (CEC), for example, with more than 65 employees, is a Vermont-based company that distributes tankless water heaters. It has no direct-to-customer sales. CEC products are available through home centers, hardware groups, catalogs, Internet stores, and plumbing and heating distributors. Webbased sales of water heaters appear to have represented about 2 percent of the market in 1996 (Cooper et al.) but have grown in recent years.

Most water heaters in new homes appear to be selected by the builder or by the contractor who installs the appliance. Architects involved in customized new home construction may also be responsible for model selection. Homeowners seeking replacement units might make the purchase decision, or might leave it to the installation contractor.

\subsubsection{The Impact of Mandates}

Standards continue to influence HVAC designs, forcing manufacturers to rework designs to meet stricter and stricter requirements. Some of these mandates could provide a competitive advantage for electric water heating products. The three-phase ANSI Standard Z21.10.1a-2002 mandate, which will be fully implemented by July 2005, requires manufacturers to design all U.S.-made gas residential water heaters of 75,000 BTUs or less to be flammable vapor ignition resistant (FVIR). The first phase affected conventional gas water heater models. In working to meet the new standards, water heater producers have had fewer resources for developing new product designs.

\subsubsection{Technological Innovations in the Appliance Industry}

Technological innovations are frequent in the appliance industry, with improvements in operation and design continually being integrated into everything from refrigerators to toasters. There are several new water-heating technologies available today, including hot water recirculator systems and tankless water heaters. But According to Doug Young, vice president and general manager for North American Residential Sales, Marketing, and Distribution at Lennox Industries Inc., the HVAC industry's main focus shouldn't be technology, but the consumer. Fred Keller, vice president of Residential Engineering for Carrier Corp., agrees. "The biggest challenge in designing to meet consumer demands is not the technology, but truly understanding the voice of the consumer. The most positive move is the change from just providing boxes that heat and cool to providing integrated solutions that heat, cool, clean, and dehumidify the air, while at the same time provide a piece of mind for the homeowner." (Appliance Manufacturer, November 2003) 


\section{CONCLUSIONS AND RECOMMENDATIONS}

To assess the market for the integrated appliance, ORNL and Clemson investigated several issues. Is there a market for the WHD? What would be the most attractive position for marketing it? Are there any problems or issues that might be associated with its use? Through preliminary discussions with representatives of relative market segments, a target market was identified, and additional discussions were held in August 2004 with 15 representatives of 3 key target market audiences for the dehumidifying water heater:

- commercial building managers (hospitals, hotels, and an assisted living facility)

- plumbers (owners of local companies and plumbing departments of Lowe's, Home Depot, and Sears)

- builders (builders of new residential home construction and a manufactured home builder)

These interviews are summarized in Appendix D.

Most of the discussions revealed that the representatives did perceive value in the dual-service appliance. The following key issues were identified for consideration by the technical design team and the market assessment team:

- The retail price of the end unit needs to be very cost competitive with existing standard electric water heaters.

- There will be strong competition with gas as a fuel source, as many new subdivisions are being designed for homes with gas.

- The end product will need to have a long warranty, be easy to install, and have clear instructions as to who call for maintenance (plumber or electrician).

- The noise level of the unit should be minimized.

- Building code requirements in target markets for the unit should be reviewed (i.e., managing drainage system).

- Size of the unit may be an issue in some locations (some closets in the southeast are 24 inches wide while the unit is projected to be 26 inches wide).

The residential and commercial target markets for the unit that were suggested by the fifteen representatives in interviews are consistent with the market research conducted and documented in the report:

- Markets in the Southeast where less use of air conditioning system to keep homes cool would be beneficial;

- Markets in the Northeast and Midwest where basements are most common; and

- Markets in the Northwest where humidity and mold/mildew issues are most prevalent.

These interviews are summarized in Appendix D. The following conclusions were gleaned from analyzing the interview summaries and studying the market literature.

- There is some perceived value in the new technology; however, the value is not quantifiable until the energy savings and dehumidification levels are solidified. The investment costs and energy consumption of the integrated appliance should be compared to the costs and consumption of a traditional water heater plus a dehumidifier. 
- Integrated WHDs should be sold at a price close to that of existing technology — standard electric water heaters as well as dehumidifiers are priced relatively low.

- Energy savings and Energy Star ${ }^{\circledR}$ certification would facilitate the integrated appliance’s marketability, especially with utilities and advocates.

- When their water heaters fail, homeowners make quick product-replacement decisions. Information on the new technology should be direct, easily accessible, and easy to understand (i.e., provides hot water, cools air in home, saves energy, incurs only a small increase in the initial cost, provides short payback, etc.).

There are several themes that emerged from the overview of the market and the analysis of the consumer values discussions. A benefit of the integrated WHD is that he dehumidifier produces cool air, in sharp contrast to traditional dehumidifiers, which produce hot air.

Some disadvantages/obstacles include:

- Many water heaters are installed in areas that would not benefit from either dehumidification or production of cool air, limiting the ability to market and price based on those additional attributes. For the dehumidification/cool air attribute to be of value to consumers, the HPWH should be located in an area needing dehumidification and/or cool air such as a utility closet in the living space of the house or apartment or in an enclosed basement. If the water heater is located in an unconditioned crawl space or garage, the dehumidification/cool air attribute may be of limited value.

- When a water heater is installed as part of new construction, the builder/contractor chooses the model. Because they do not incur the cost savings or dehumidification benefits, there is little incentive to choose a system that costs more than a standard item.

- Water heaters are often replaced due to their eventual failure. Given the urgency of the situation, many homeowners will rely on a plumber to choose any readily available model. The potential longterm cost savings and the dehumidification benefits would likely be of less importance than the quick replacement of the water heater.

Promising situations include:

- In highly humid areas of the country, particularly the Northwest, the Southeast, and some coastal areas, installing the appliance in a utility closet, perhaps in a subterranean location of an apartment or house, would be advantageous if the promise of dehumidification were sufficient to motivate purchase of an integrated WHD.

- Installing an integrated WHD in newly constructed, manufactured housing would be particularly beneficial to Energy Star® units where the overall energy savings for the home can offset some of the initial costs.

- Installing an integrated WHD in an institutional laundry, such as in apartment complexes, dormitories, hospitals, or assisted-living facilities, could provide relief from the humidity and heat generated by the washers and driers. Additional benefits would be energy savings and cooler air.

- Integrated WHDs can offset the high heat and humidity that plague specialized industrial situations where a localized source of hot water in an enclosed environment is necessary.

The retail price, energy savings, dehumidification level, product name, and supply-chain entry for the new technology should be reviewed. Niche deployment opportunities for the integrated WHDs, such as manufactured housing, commercial laundries, and assisted-living facilities, should be investigated, and partnerships with supply-chain stakeholders should be initiated. 
To enhance the integrated WHD's marketability, when the first prototypes are built and an estimated retail price is set, a small focus-group survey of consumers in the target-market should be conducted. A field trial demonstration program will also provide important feedback to the product design team. The market assessment team identified a new home builder, a contractor, and a distributor who are interested in participating in the field trial program for the integrated WHD. 


\section{BIBLIOGRAPHY AND REFERENCES}

Allergy and Asthma Foundation of America 2004.

http://www.aafa.org/templ/display.cfm?id=304\&sub=515

Allergy Consumer Review Issue \#65. http://www.allergyconsumerreview.com/current-issue.html.

"Everything You Wanted To Know About Dehumidifiers," by B. Cobe, AllergyBuyersClub.com

Air Conditioning, Heating \& Refrigeration News 2004. "Products designed to balance humidity," February 23, 2004 v221 i8 p22(1).

Appliance Magazine, September 2002. “A Portrait of the U.S. Appliance Industry.”

Appliance Manufacturer, November 2003. “The technology influence,” p. 50.

Applied and Environmental Microbiology, April 2002, p. 1743-1753, Vol. 68, No. 4.

ARI Annual Meeting Highlights, November 2003.

Claims Magazine 2000. “Mold and Mildew: A Creeping Catastrophe,” by E. L. Herndon, Jr. and C. S. Yang.

Contractor Magazine, June 2004. “Water Heater Market Contends With New Regs, Higher Costs,” by R. P. Mader.

Delano Data Insights May 2004. AHAM Forecast in Appliance Manufacturer.

Energy Information Administration (EIA) 2001. Residential Energy Consumption Survey 2001

Housing Characteristics Data Tables. http://www.eia.doe.gov/emeu/recs/recs2001/detail tables.html.

Energy Star 2004. http://www.energystar.gov/

Frost \& Sullivan 2003. "United States Water Heating Equipment Markets.”

Gas Appliance Manufacturers’ Association (GAMA) April 2003 Consumers Directory.

http://healthandenergy.com/mold.htm

http://www.aafa.org/

http://www.bradfordwhite.com/

http://www.hotwater.com/

http://www.nahbrc.org/index.asp

http://www.newhomesource.com/Market/articles/foundations.htm?refer=DSI. "Building on a Solid Foundation,” by S. Karasik.

http://www.newhomesource.com/market/articles/newhomesecho.htm. "Regional Trends in New Home Designs,” by D. Amoruso. 
http://www.rheem.com

http://www.thisoldhouse.com/toh/html/almanac/almanac_030304_march.html

http://www.vaughncorp.com/tkbusinessop.html

LBNL 2004. "Dampness and Mold Growth in Buildings: A National Academy Study.” Environmental Energy Technologies Division, Lawrence Berkeley National Laboratory, Summer Newsletter, Vol. 5, No. 3, p. 1.

National Association of Home Builders 2004. http://www.nahb.org/

Picket Fence Preview, Inc. 1997. "Trends in Single Family Homes: More space, more rooms and more amenities," by S. Portnoy.

Reeves Journal, February 2004. "Hot water recirculators gain in popularity.”

Shelton, B. G.; Kirkland, K. H.; Flanders, W. D.; Morris, G. K. Applied and Environmental Microbiology, Vol. 68, No. 4, 2002. pp. 1743-1753.

The Freedonia Group, Snapshots International August 2003. “US Dehumidifiers 2003: Cooling Equipment—HVAC Equipment Dehumidifiers.”

The Freedonia Group. Snapshots International August 2003a. “U.S. Electric Water Heaters 2003.” http://dx.doi.org/10.1337/us081093.

USA Today.com Weather 2004. "Wrong humidity turns your house into a hassle," by the Associated Press, February. http://www.usatoday.com/weather/resources/basics/2004-02-01-homehumidity_x.htm 


\section{APPENDIX A. PRICING INFORMATION}




\section{ELECTRIC WATER HEATERS}

To compare prices of leading manufacturers in the electric water heating market, a spreadsheet was created with information from the manufacturer's web addresses or from any promotional material from a local store location in Oak Ridge, Tennessee. Comparisons show that the average electric water heater (50 gallons) is around \$238.00, and offered in neutral colors. Most of the water heaters had an Energy Star certification label. The results are graphed below and a data sheet summary is provided at the end of this section:

\section{Cost and installation price by brand}

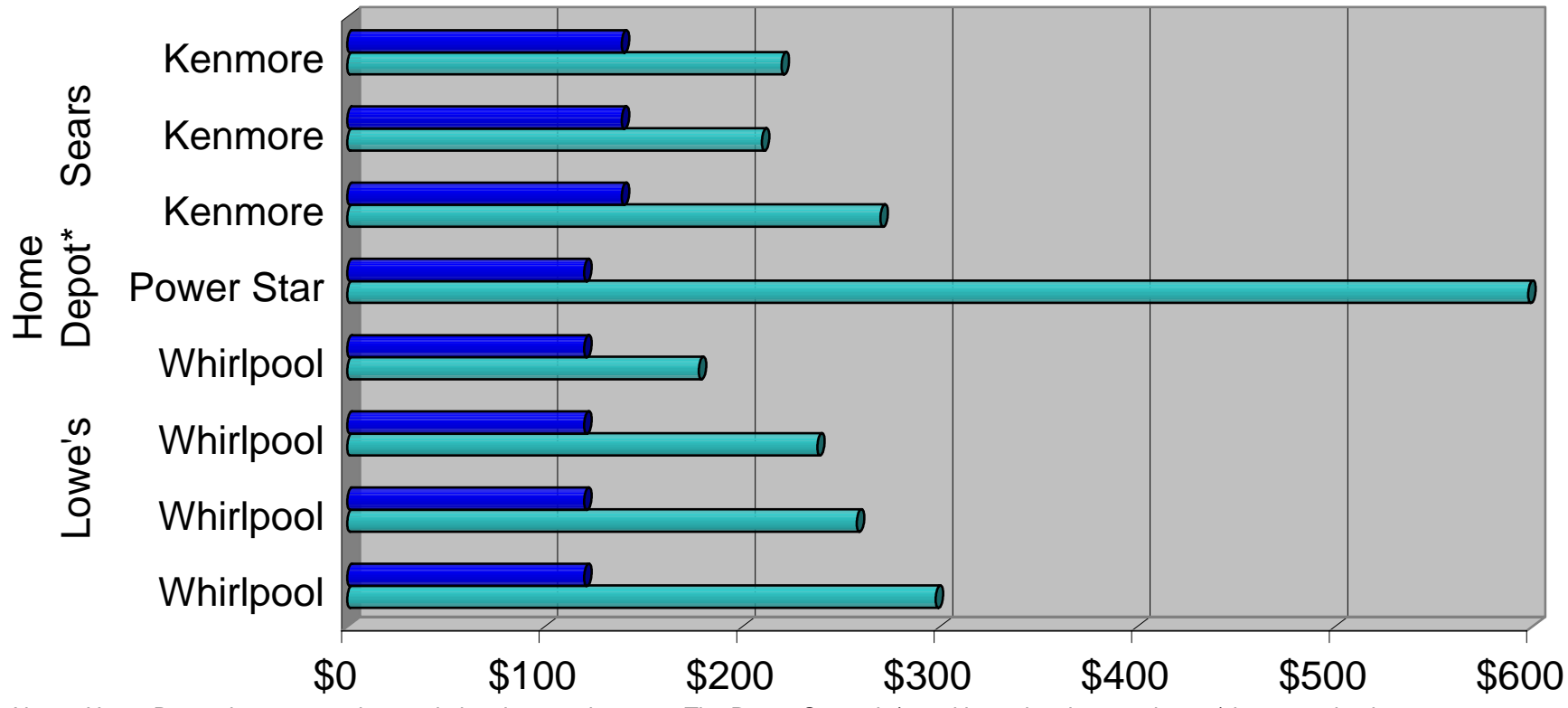

Notes: Home Depot does not stock 50-gal electric water heaters. The Power Star unit (a tankless electric water heater) is a 40-gal unit.

Prices of 50-gal electric water heater units at Lowe's and Sears' were averaged together using the data collected from their respective websites on July 20,2004 , for an average price of $\$ 238.00$.

$\square$ Cost of Unit $\square$ Basic Installation Cost 


\section{DEHUMIDIFIERS}

The information from the 50-gallon electric water heaters was similar to the dehumidifiers. All nine dehumidifiers described below are offered in a neutral color of white. Energy Star is labeled on almost all the models. Each unit has similar control options installed on them. Comparisons show that the average dehumidifier is around $\$ 180$. The information from the spreadsheet was gathered by reviewing information on the manufacturer's web address or from promotional material from a store located in Oak Ridge, Tennessee. Comparisons are shown in the bar chart below with a data sheet providing more information at the end of this section:

\section{Dehumidifiers: retail price and capacity comparisons}

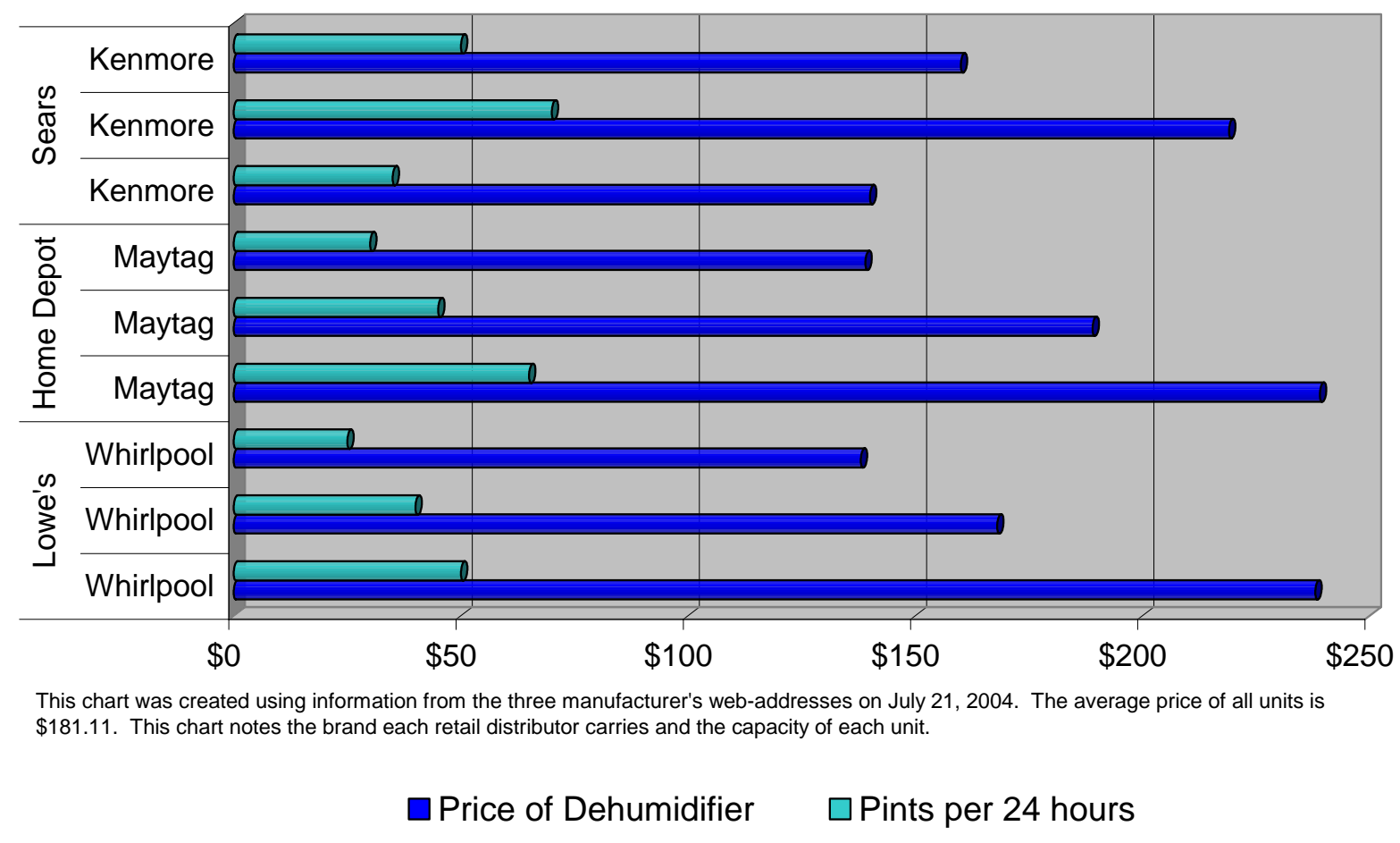




\begin{tabular}{|c|c|c|c|c|c|c|}
\hline \multicolumn{7}{|c|}{ Electric Water Heaters (40/50 gal) } \\
\hline $\begin{array}{c}\text { Retail } \\
\text { Distributor }\end{array}$ & Brand & Model \# & Price & $\begin{array}{c}\text { Installation } \\
\text { Costs }\end{array}$ & $\begin{array}{c}\text { Energy } \\
\text { Star } \\
\text { certified }\end{array}$ & Source \\
\hline \multirow[t]{4}{*}{ Lowe's } & Whirlpool & EE3Z50RD055V & $\$ 298$ & $\$ 120$ & Yes & http:www.lowes.com \\
\hline & Whirlpool & EE3J50RD045V & $\$ 258$ & $\$ 120$ & Yes & http:www.lowes.com \\
\hline & Whirlpool & EE2H50RD045V & $\$ 238$ & $\$ 120$ & Yes & http:www.lowes.com \\
\hline & $\begin{array}{l}\text { Whirlpool } \\
\text { Power }\end{array}$ & E1F50RD045V & $\$ 178$ & $\$ 120$ & No & http:www.lowes.com \\
\hline Depot* & Star & AE125 & $\$ 598.00$ & $\$ 120$ & No & http:www.homedepot.com \\
\hline \multirow[t]{3}{*}{ Sears } & Kenmore & 32956 & $\$ 269.99$ & $\$ 139$ & No & http:www.sears.com \\
\hline & Kenmore & 32666 & $\$ 209.99$ & $\$ 139$ & No & http:www.sears.com \\
\hline & Kenmore & 32686 & $\$ 219.99$ & $\$ 139$ & No & http:www.sears.com \\
\hline \multicolumn{7}{|c|}{ *Home Depot sells a 40-gal tankless and does not offer 50-gal electric water heaters } \\
\hline \multicolumn{7}{|c|}{ Dehumidifiers } \\
\hline $\begin{array}{c}\text { Retail } \\
\text { Distributor }\end{array}$ & Brand & Model \# & Price & $\begin{array}{c}\text { Pints per } \\
24 \mathrm{hr} \\
\end{array}$ & $\begin{array}{c}\text { Energy } \\
\text { Star } \\
\text { Certified } \\
\end{array}$ & Source \\
\hline \multirow[t]{3}{*}{ Lowe's } & Whirlpool & AD50USL & $\$ 238$ & 50 & Yes & Visit to local store location \\
\hline & Whirlpool & AD40DSL & $\$ 168$ & 40 & Yes & Visit to local store location \\
\hline & Whirlpool & AD25BBL & $\$ 138$ & 25 & No & Visit to local store location \\
\hline \multirow[t]{3}{*}{ Home Depot } & Maytag & M7DH65B2A & $\$ 239$ & 65 & Yes & http:www.homedepot.com \\
\hline & Maytag & M7DH65B2A & $\$ 189$ & 45 & Yes & http:www.homedepot.com \\
\hline & Maytag & M3DH30B2A & $\$ 139$ & 30 & No & http:www.homedepot.com \\
\hline \multirow[t]{3}{*}{ Sears } & Kenmore & 54351 & $\$ 140$ & 35 & Yes & http:www.sears.com \\
\hline & Kenmore & 54701 & $\$ 219$ & 70 & Yes & http:www.sears.com \\
\hline & Kenmore & 54501 & $\$ 160$ & 50 & Yes & http:www.sears.com \\
\hline
\end{tabular}

Notes: These data were collected July 20-21, 2004. They show a comparison summary of the unit prices from leading manufacturers on their electric water heaters and

dehumidifiers. The installation cost and Energy Star certification information was gathered by calling the local store locations in Oak Ridge and Knoxville, TN. 
APPENDIX B. WATER HEATERS AND DEHUMIDIFIER MANUFACTURERS AND OTHER HVAC APPLIANCE AFFILIATES 
This appendix lists some major manufacturers and retailers of water heaters and dehumidifiers and provides contact information.

\begin{tabular}{|c|c|}
\hline \multicolumn{2}{|r|}{ Manufacturers-Dehumidifiers } \\
\hline Aprilaire & $608-257-8801$ \\
\hline Amana Appliances & $800-843-0304$ \\
\hline American ALDES Ventilation & $800-255-7749$ \\
\hline $\begin{array}{l}\text { Dampp/Chaser Electronics } \\
\text { Corp. }\end{array}$ & $800-438-1524$ \\
\hline Dectron Internationale & $\begin{array}{l}4300 \text { Poirier Boulevard } \\
\text { Montreal, Quebec } \\
\text { Canada, H4R 2C5 } \\
\text { (514) 334-9609 } \\
\text { (514) 334-9184 Fax }\end{array}$ \\
\hline Delonghi America, Inc. & $\begin{array}{l}1 \text { Park } 80 \text { PIz W FL } 4 \\
\text { Saddle Brook, NJ 07663-5808 } \\
\text { Phone: } 201-909-4000\end{array}$ \\
\hline Fedders Appliances & $\begin{array}{l}505 \text { Martinsville Rd., Westgate Corporate Ctr. } \\
\text { Liberty Corner, NJ 07938-0813 } \\
\text { Phone: } 908-604-8686 \\
\text { Fax: } 908-604-0715 \\
\text { www.fedders.com }\end{array}$ \\
\hline $\begin{array}{l}\text { Friedrich Heating and Air } \\
\text { Conditioning Inc, }\end{array}$ & $\begin{array}{l}153 \text { Highland Ter } \\
\text { Pitman, NJ 08071-1507 } \\
\text { Phone: 856-589-0559 }\end{array}$ \\
\hline GE Appliances & $\begin{array}{l}\text { Appliance Park } \\
\text { Louisville, KY } 40225 \\
\text { Phone: } 502-452-4311 \\
\text { Fax: } 502-452-0352\end{array}$ \\
\hline Haier America & $\begin{array}{l}1356 \text { Broadway } \\
\text { New York, NY } 10018 \\
\text { Phone: 212-594-3330 } \\
\text { Fax: 212-594-9667 } \\
\text { www.haieramerica.com }\end{array}$ \\
\hline Heat Controller Inc. & $\begin{array}{l}1900 \text { Wellworth Ave. } \\
\text { Jackson, Ml } 49203 \\
\text { Phone: } 517-787-2100 \\
\text { Fax: } 517-787-9341 \\
\text { www.heatcontroller.co }\end{array}$ \\
\hline \multicolumn{2}{|r|}{ Manufacturers-Water Heaters } \\
\hline American Water Heating & $\begin{array}{l}\text { American Water Heater Company } \\
500 \text { Princeton Rd. } \\
\text { Johnson City, TN } 37601 \\
\text { Phone: } 423-283-8000 \\
\text { http://www.americanwaterheater.com/ }\end{array}$ \\
\hline A.O. Smith & $\begin{array}{l}\text { AO Smith Water Products Company } \\
\text { World Headquarters } \\
11270 \text { West Park Place } \\
\text { Milwaukee, WI } 53224 \\
\text { Tele: } 414-359-4000 \\
\text { Fax: 414-359-4064 } \\
\text { http://www.hotwater.com/ }\end{array}$ \\
\hline
\end{tabular}




\begin{tabular}{|c|c|}
\hline Bradford White & $\begin{array}{l}\text { Bradford White } \\
\text { Corporate Headquarters } \\
725 \text { Talamore Drive } \\
\text { Ambler, PA } 19002 \\
\text { Phone: 215-641-9400 } \\
\text { Fax: } 215-641-1612 \\
\text { http://www.bradfordwhite.com/ }\end{array}$ \\
\hline Rheem & $\begin{array}{l}\text { 334-260-1364, } \\
\text { Rheem Corporate Office } \\
405 \text { Lexington Avenue, } 22^{\text {nd }} \text { floor } \\
\text { New York, New York 10174-0307 } \\
\text { Phone: } 212-916-8100 \\
\text { Fax: } 212-916-8109 \\
\text { http://www.rheem.com }\end{array}$ \\
\hline Whirlpool Corp. & $\begin{array}{l}\text { http://www. whirlpoolcorp.com/general/contact/default.asp } \\
\text { Benton Harbor, Michigan 49022-2692 } \\
2000 \text { N. M-63 } \\
\text { 269-923-5000 } \\
\text { christopher jwyse@whirlpool.com }\end{array}$ \\
\hline Marathon & $\begin{array}{l}\text { http://www. marathonheaters.com/index.html } \\
\text { Water Heater Innovations, Inc. } \\
3107 \text { Sibley Memorial Highway } \\
\text { Eagan, MN 55121-1604 } \\
\text { bjackson@rheem.com }\end{array}$ \\
\hline
\end{tabular}

\begin{tabular}{|c|c|}
\hline \multicolumn{2}{|c|}{ Associations and Societies } \\
\hline $\begin{array}{l}\text { Association of Home Appliance } \\
\text { Manufacturers }\left(\text { AHAM) }{ }^{a}\right.\end{array}$ & $\begin{array}{l}\text { Suite } 402,1111 \text { 19th St., NW } \\
\text { Washington, DC } 20036 \\
\text { (202)872-5955 } \\
(202) 872-9354 \text { (fax) }\end{array}$ \\
\hline $\begin{array}{l}\text { Air-Conditioning \& Refrigeration } \\
\text { Institute }(A R I)\end{array}$ & $\begin{array}{l}4100 \text { N. Fairfax Drive, Suite } 200 \\
\text { Arlington, VA } 22203 \\
703-524-8800 \\
703-528-3816\end{array}$ \\
\hline $\begin{array}{l}\text { American Society of Heating, } \\
\text { Refrigerating and Air-Conditioning } \\
\text { Engineers (ASHRAE) }{ }^{c}\end{array}$ & $\begin{array}{l}1791 \text { Tullie Circle, N.E. } \\
\text { Atlanta, GA } 30329 \\
\text { www.ashrae.org } \\
(404) 636-8400 \\
(404) 321-5478\end{array}$ \\
\hline $\begin{array}{l}\text { Gas Appliance Manufacturers } \\
\text { Association }\end{array}$ & $\begin{array}{l}2107 \text { Wilson Blvd., Suite } 600 \\
\text { Arlington, Virginia } 22201 \\
\text { (703) 525-7060 }\end{array}$ \\
\hline
\end{tabular}




\section{APPENDIX C. HUMIDITY, MOLD, AND FUNGUS}


Relative humidity is a function of the air temperature - the warmer the temperature, the lower the relative humidity for a given amount of moisture in the air. For example, the same amount of moisture that would saturate the air at $40^{\circ} \mathrm{F}(100 \%$ relative humidity) would produce a value of only 24 percent relative humidity at $80^{\circ} \mathrm{F}$. Consequently, for example, Florida's relative humidity may not seem so high because its temperature is warm. In addition to the relative humidity map (Fig. C.1), maps showing number of days with precipitation (C.2) and number of hours with sunshine (C.3) are included to provide a broader picture of factors influencing mold growth. (All maps at www.ncdc.noaa.gov.)

One of the benefits of the integrated appliance is that in controlling moisture, it reduces mold, mildew, and the health threat posed by these. Figure C.4 displays the distribution of airborne fungal concentrations by region and season for indoor and outdoor samples. Figure C.5 shows the distribution of the indoor/outdoor fungal ratio for buildings by region and season (Applied and Environmental Microbiology 2002).

Fungi are the broad classification of spore producing organisms usually classified as plants that lack chlorophyll. Fungi include molds, mildews, rusts, smuts, mushrooms and yeasts. There are approximately 50,000 known species of fungi in existence. Fungi live in many types of environments. They thrive in moist, tropical climates. Fungi do not contain chlorophyll and, therefore, cannot manufacture their own food. Fungi maintain their existence by absorbing the minerals, sugars and water from the host on which they live. Fungi use spores as a reproductive mechanism. The wind scatters the spores which then establish and develop into new fungi.

Molds are a member of the fungi family. Molds do not contain chlorophyll and, therefore, cannot produce their own food. Molds can live off of a tremendous variety of food sources as well as reproduce in large quantities. Mold spores travel through the indoor and outdoor air continually. When mold spores land on a damp spot indoors, they may begin growing and digesting whatever they are growing on in order to survive. There are molds that can grow on wood, paper, carpet, and foods. When excessive moisture or water accumulates indoors, mold growth will often occur, particularly if the moisture problem remains undiscovered or un-addressed.

Molds primarily thrive and become a problem when the relative humidity level is above 60 percent, with temperatures between 50 and $90^{\circ} \mathrm{F}\left(10\right.$ to $32^{\circ} \mathrm{C}$.) and a $\mathrm{pH}$ from 3 to 8 . Molds also tend to be more robust in poorly ventilated areas with little air movement to disrupt their growth. There is no practical way to eliminate all mold and mold spores in the indoor environment; the way to control indoor mold growth is to limit moisture. During humid weather, avoid excessive ventilation and use an air conditioner and/or dehumidifier to keep relative humidity below 60 percent. During drier weather, simply providing adequate ventilation may be sufficient to prevent excessively high indoor relative humidity (http://healthandenergy.com/mold.htm). 
參 Mean Total Sunshine Hours for US - Annual

Main Key Help

Annual

HOURS

$<2000$

$2000-2200$

$2201-2400$

$2401-2600$

$2601-2800$

$2801-3000$

$3001-3200$

$3201-3400$

$>3400$

\section{Land Features}

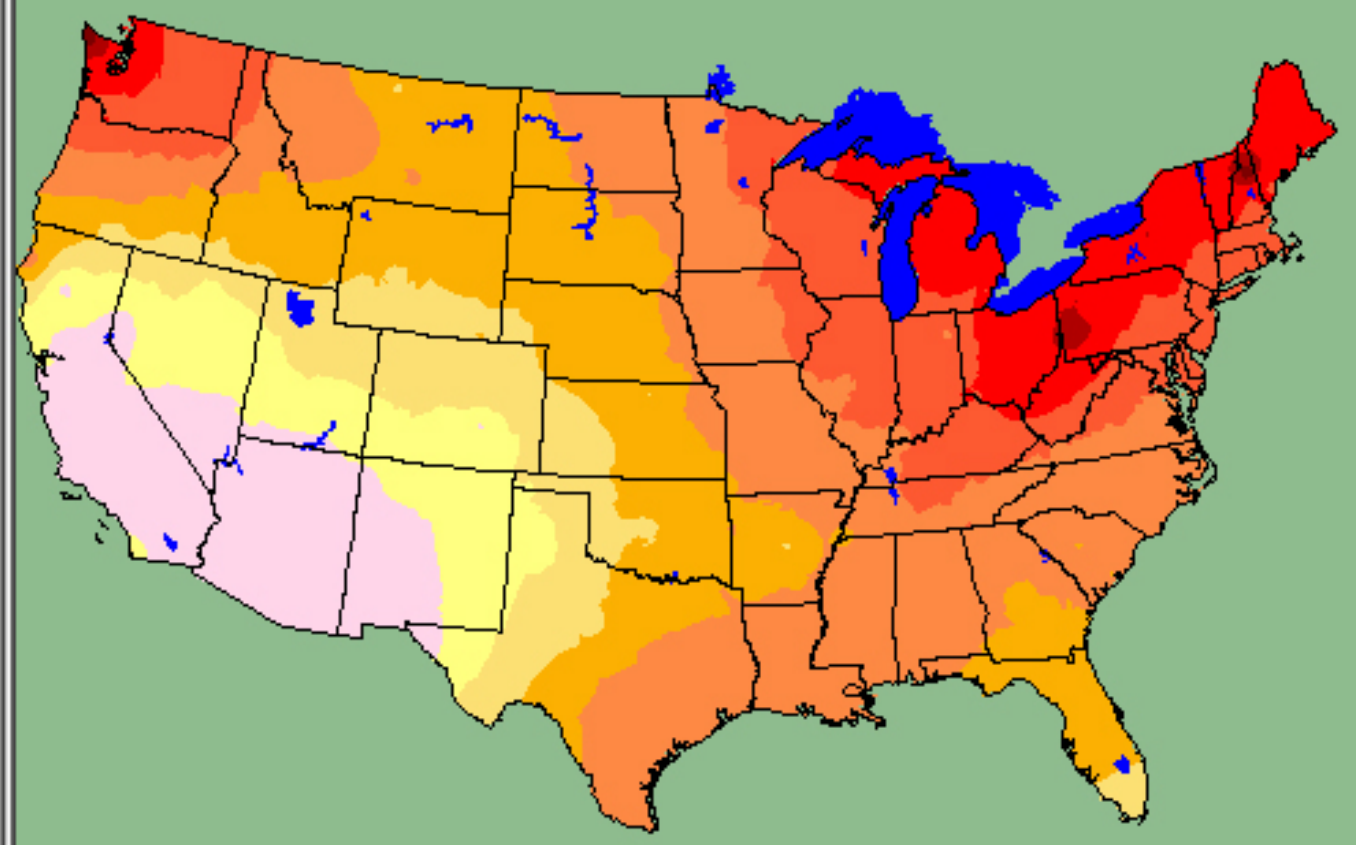

Monthly Maps

Fig. C.2 Mean total sunshine hours for United States (annual) Source: Desktop Climate Atlas Version 1.0. 
道 Mean Days w/ Measurable Precipitation for US - Annual

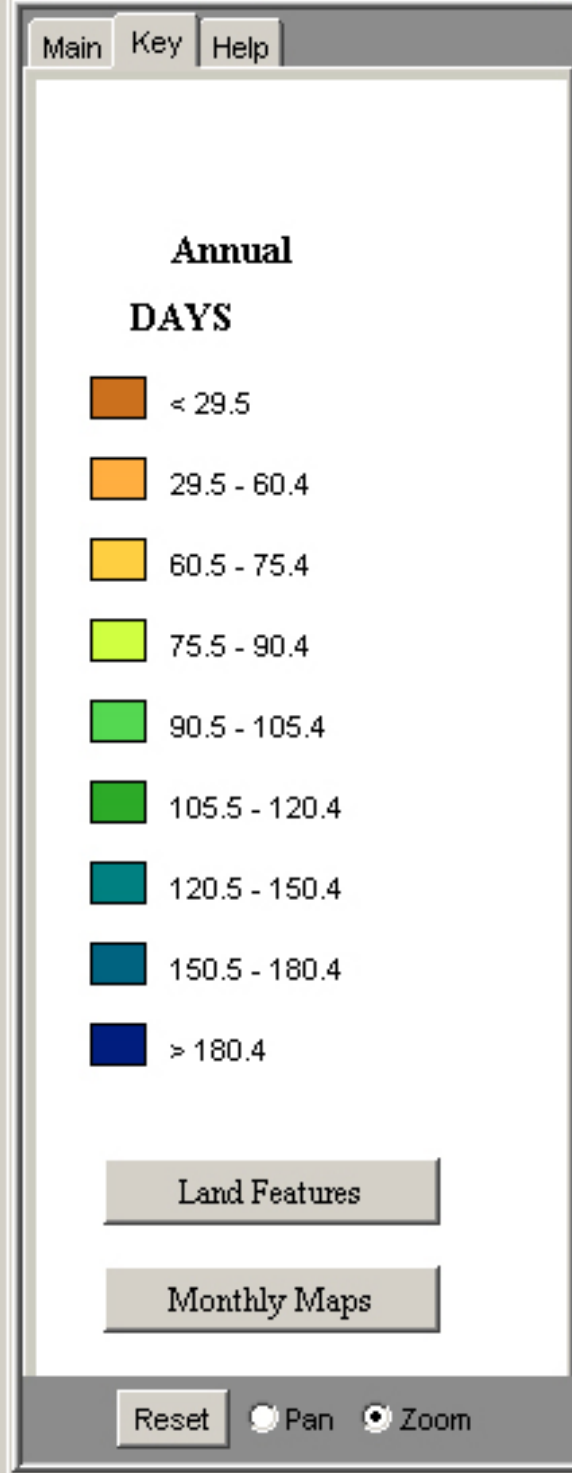

Fig. C.3 Mean days with measurable precipitation for the United States (annual). Source: Desktop Climate Atlas Version 1.0 


\section{Far West}

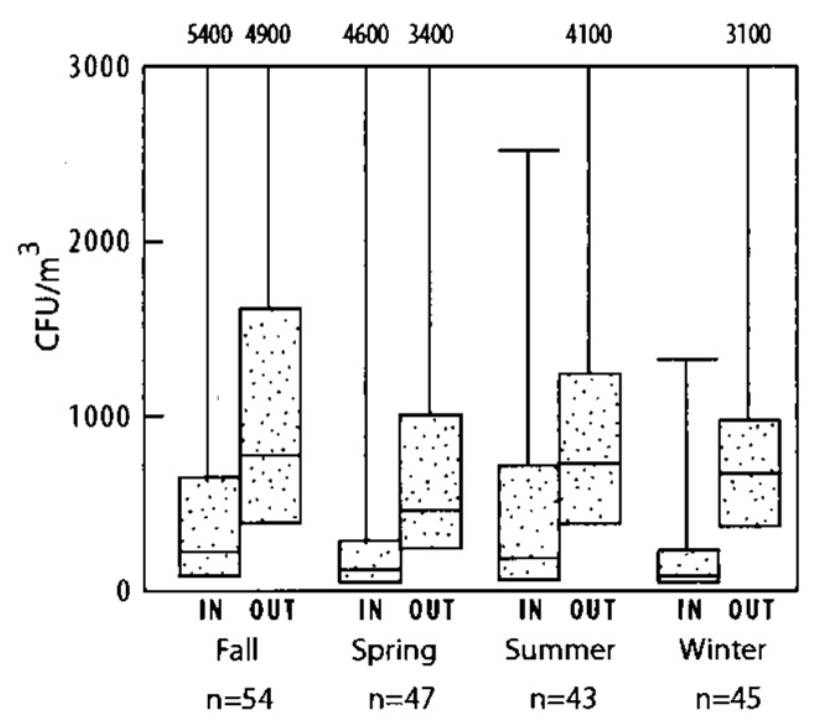

\section{Northwest}

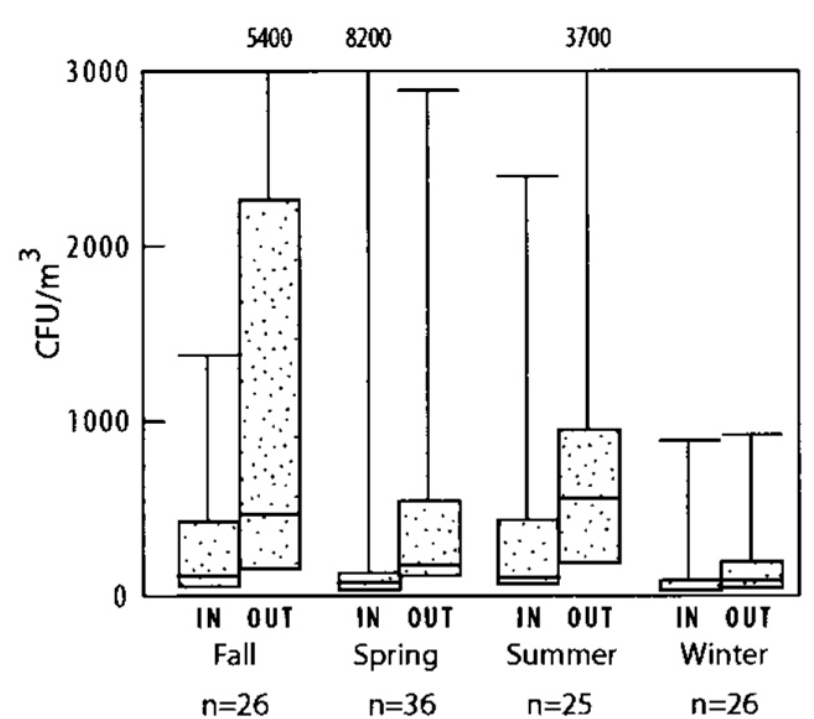

Midwest

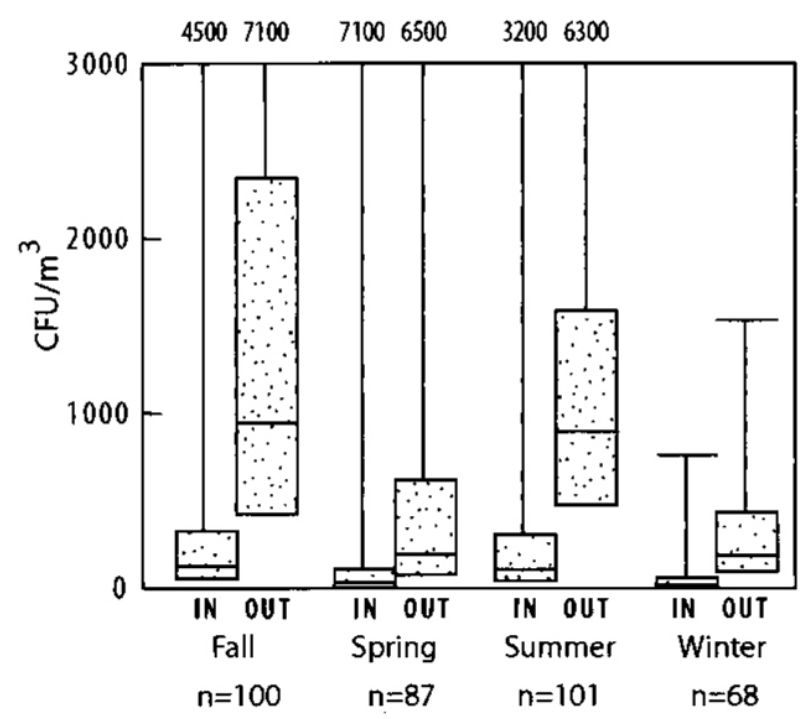

Southeast

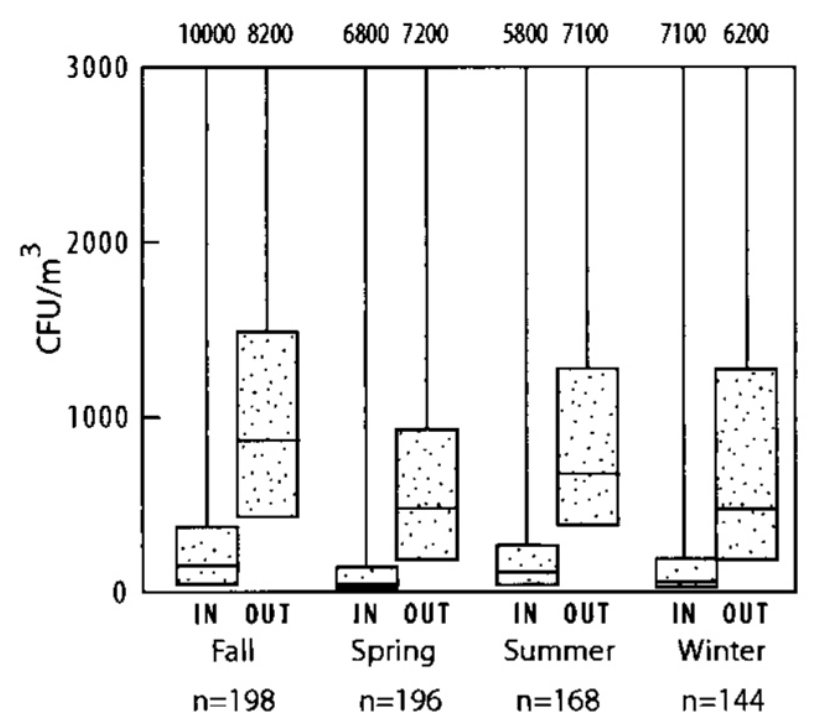

\section{Northeast}

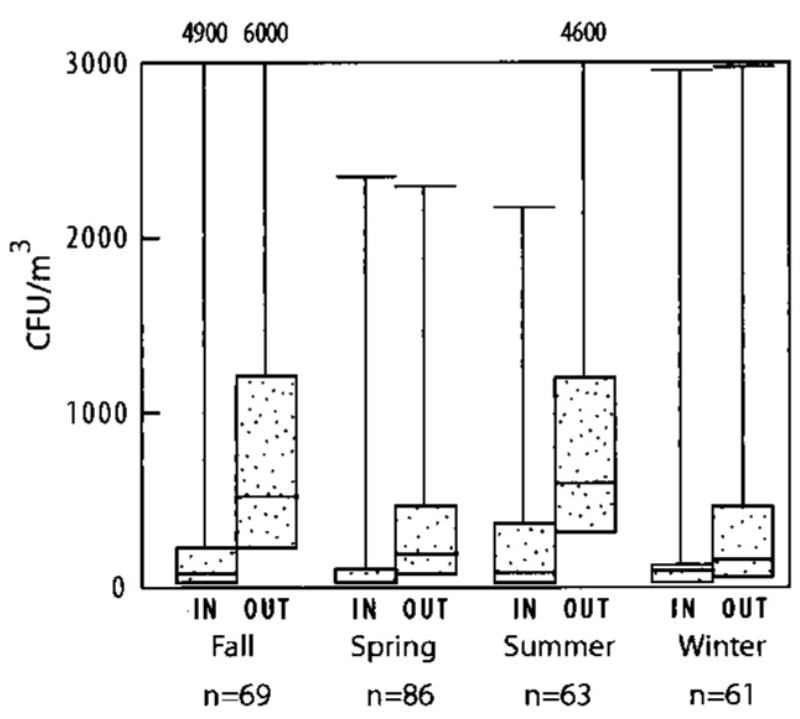

Southwest

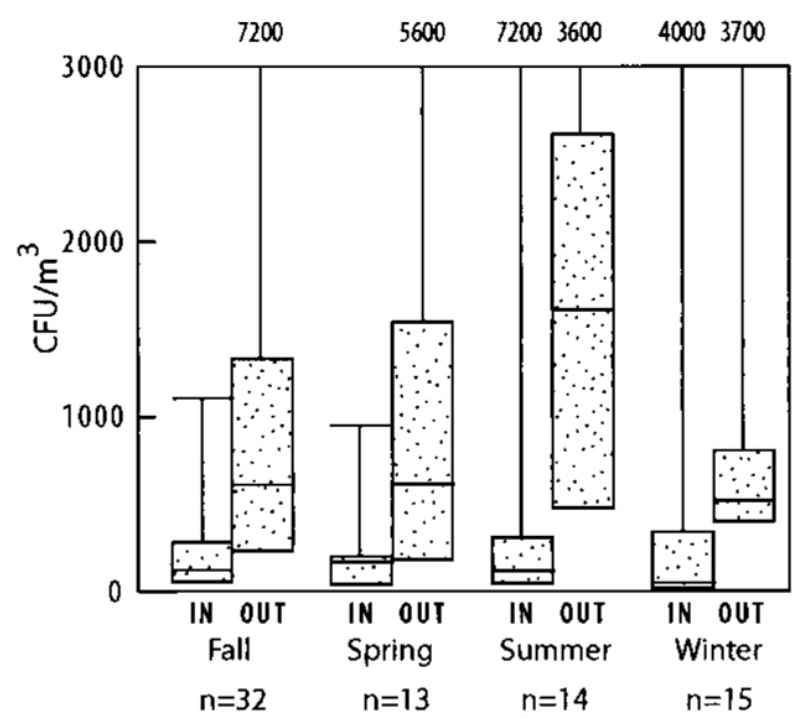

Fig. C.4 Distribution of airborne fungal concentrations by region and season for indoor and outdoor samples.

The dotted bars indicate the inner quartiles ranging from the 25th percentile to the 75th percentile, and the horizontal lines indicate the median fungal concentrations. The top of the vertical line represents the maximum observed value. The

maximum value is shown at the top of the figure when it exceeds the scale. 
Far West

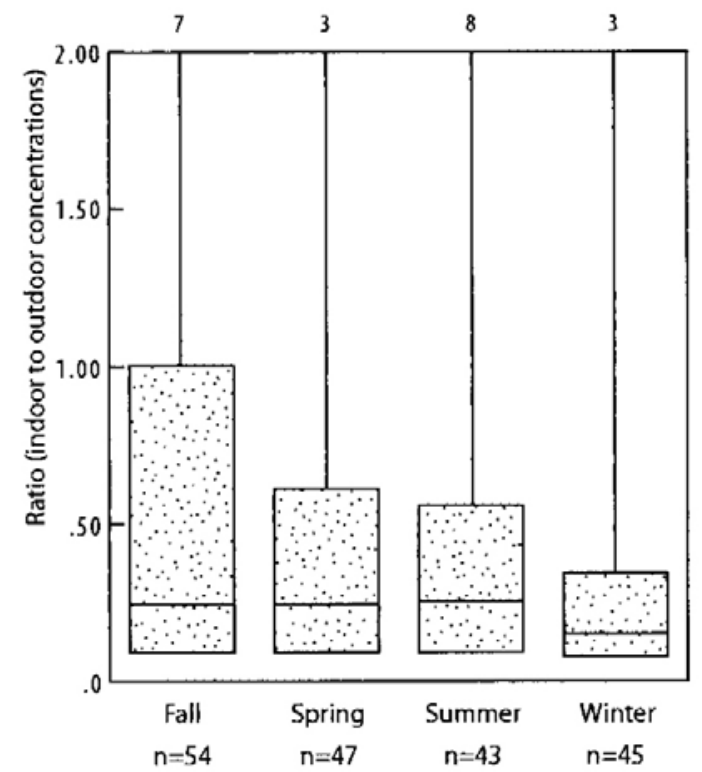

Northwest

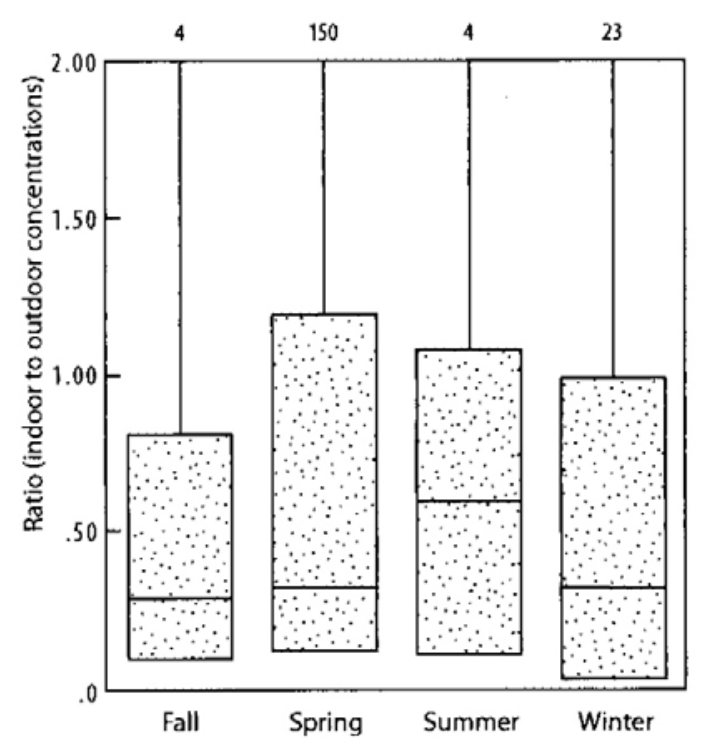

Midwest

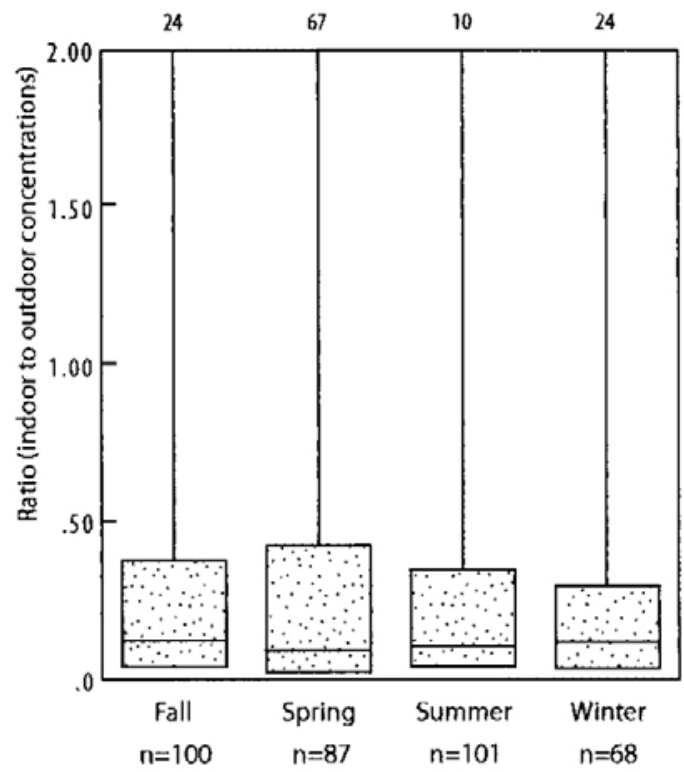

Southeast

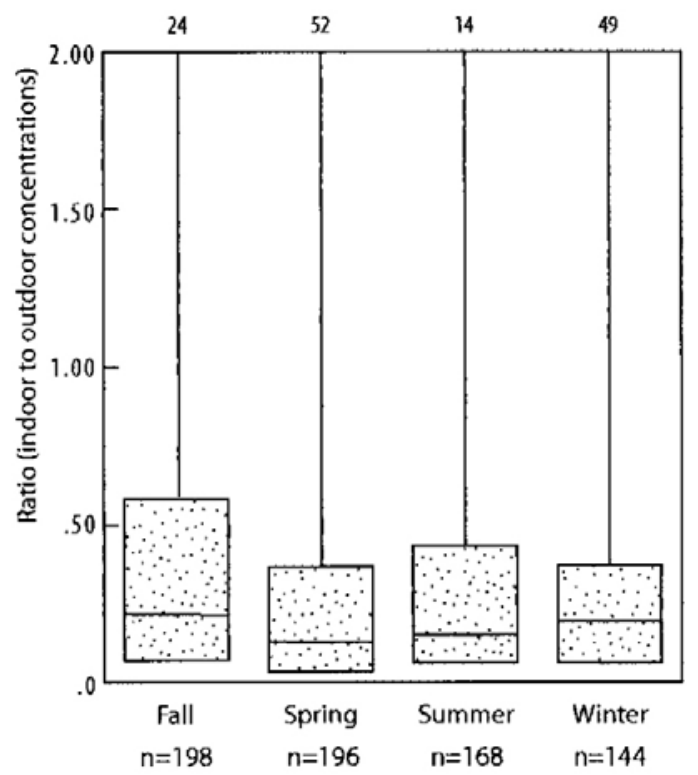

Northeast

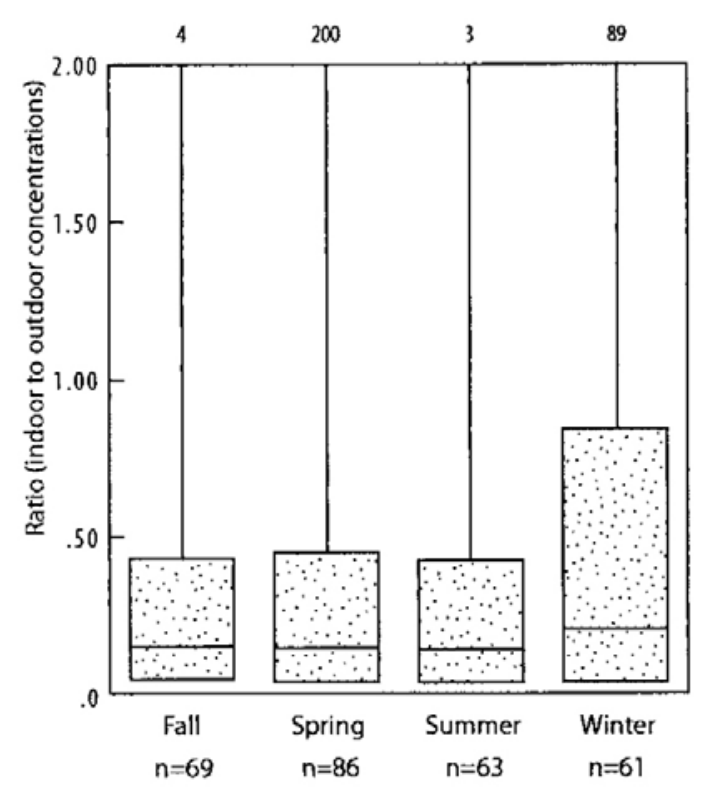

Southwest

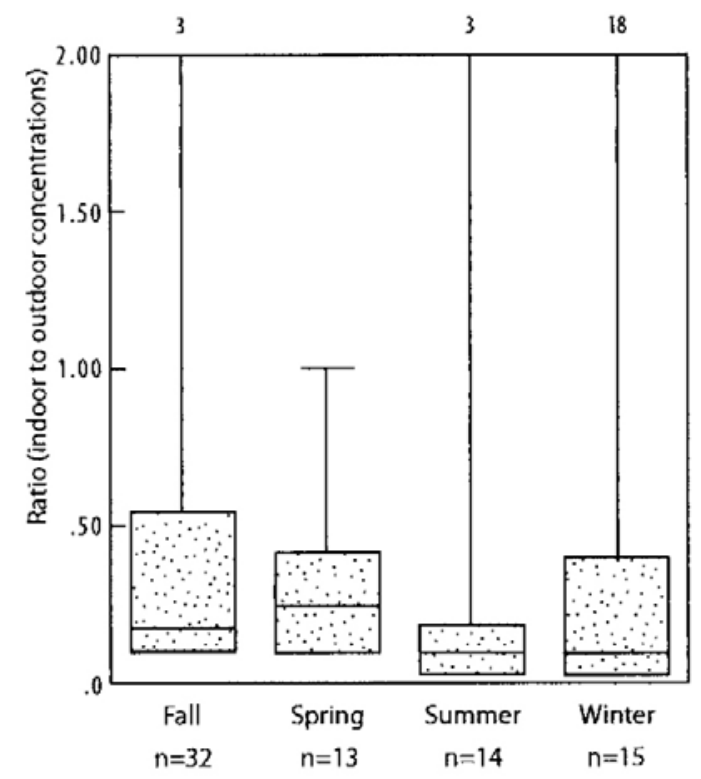

Fig. C.5 Distribution of the indoor/ outdoor fungal ratio for buildings by region and season. The dotted bars indicate the inner quartiles ranging from the 25th percentile to the 75th percentile, and the horizontal lines indicate the median fungal concentrations. The top of the vertical line represents the maximum observed value. The maximum value is shown at the top of the figure when it exceeds the scale. 


\section{APPENDIX D. CONSUMER VALUES DISCUSSION RESULTS}

To understand the potential consumer values and markets for the integrated dehumidifier/water heater, discussions were held with representatives from all major sectors of the supply chain for this type of product, including the manufacturers, distributors, builders, contractors, utilities, and retailers. Potential end-use customers included residential consumers and commercial building managers. Intermediaries included organizational advocates as well as other types of associations. The following provides an overall summary of the comments from each sector.

\section{Builders - Manufactured Homes}

We discussed the dehumidifying water heater with a major manufactured-home builder, who is also an Energy Star® Partner of the Year. A summary of the discussion includes:

- This builder installs both electric and gas water heaters. Electric water heaters are the norm, but most home owners now ask for gas water heaters to be included in their package.

- Water heaters are located in garages, basements, crawl spaces, utility rooms within living spaces, or other spaces such as a separate water heater compartment (closet) in a conditioned space.

- The builder's engineering department makes the decision as to which kind of water heater to install. The company just recently switched from State to Rheem. They purchase directly from the manufacturer.

- The current price for units installed in homes is around $\$ 100$. This builder sells within a wide price range, from as low as $\$ 15,000$ to as high as $\$ 102,000$. For homes in the South on the upper end of the price range, there is a potential market for an integrated WHD. An Energy Star ${ }^{\circledR}$ product would enhance this potential.

- Mold can be an issue in manufactured homes because of moisture in some of them.

\section{Builders - Residential Homes}

We discussed the integrated WHD with three major home builders.

- One builder indicated that there would be no major market in their locale because very few homes had basements in a high water table. In addition, all water heaters for these homes were gas. However, they thought there might be a market further north where basement homes predominated. This builder also indicated that the energy savings, payback and dedicated dehumidification were strong attributes in their Southeast location. Gas has become more competitive for electric water heaters in this area.

- Another builder indicated that energy savings and dehumidification of basements would be good selling points. The price is within the range of higher-end water heaters, and because most water heaters are installed in basements, and many homes have basements as garages (especially in larger homes). The best market may be for smaller homes and homes with crawlspaces where mold can be an issue. In addition, this builder indicated that most new homes are installing gas water heaters. These must be vented, which takes up more space, and furthermore, gas water heaters give off water vapor. In this case dehumidification would be an asset. 


\section{Contractors}

Four contractors in the Southeast indicated:

- Both electric and gas water heaters are installed based on demand. In areas where electric dominates, use of gas is increasing. These units are placed in a location of the house where it is easily accessed, like a basement, crawl space, closet, or garage. With new or old homes the water heaters are chosen by the homeowner. Brands installed are State Industries, Rheem, and Whirlpool.

- Most consumers liked their units because they can get hot water readily and/or that the units have good warranties.

- $\quad$ Price range of installed units is from $\$ 200$ to $\$ 650$.

- They learn about new products and technologies from experience and their customers.

- Dehumidification needs vary with area of the region.

- Homeowners would pay a low premium for a unit with the capabilities of the integrated DWH. One contractor indicated that the price would be competitive with high-end water heaters. Another said that the price was in line with a direct-vent or power-vent water heater.

- The field tests should show the product's reliability and ease of installation.

\section{Manufacturers}

We talked to representatives of major manufacturers - five of water heaters and two of dehumidifiers, who indicated:

- Dehumidifiers are generally placed throughout the home, not one specific place; however, they are mainly placed in the basement in the Midwest. Dehumidifiers are seasonal products. Marketing attributes include the size of the unit and how much water it can hold before the consumer would have to empty it. Homes with basements and/or with mold issues need dehumidification more than others.

- Water heaters are usually located in the garage, attic, utility room, closet, and basement; depending on region of the country. Many of the spaces water heaters are located are unconditioned.

- The general/plumbing contractor and/or builder usually decide which water heater to install in new homes.

- Consumers like water heaters because they readily provide hot water. One mentioned they like the new C3 technology that is nonflammable (it has a spark ignition). Consumers do not like commodity pricing, leaking, or lack of reliability of water heaters.

- Manufacturers learn about new water heaters from trade associations, their respective training departments, and market research and regulations. For new water heater systems, they look at marketability.

- Field testing data of new technologies should include long-term reliability, service reliability, ease of installation and costs, national acceptance, direct replacement for existing units, generation of volume, and noise issues.

- Consumers have a need for dehumidification, including comfort level and health concerns - they are looking for the best comfort system with the most control.

- A certain percentage of homeowners do not want to pay a premium for a water heater because they are perceived as a nuisance and an unanticipated purchase (when they break down). They are 
interested more in first cost, not life cycle cost. For instance, they might reason that heat pump water heaters only work well in limited areas of the country, are expensive, have substantial installation costs, are difficult to replace, and require frequent maintenance.

- If a dual-service water heating dehumidifier provided a 5 to 10 percent savings on utility bills it would prove valuable. A higher efficiency water heater would be a lot easier to sell than a dehumidifier. Consider renaming it instead of calling it a water heater dehumidifier.

\section{Distributors}

One Southeast distributor indicated:

- There are many different kinds of water heaters (gas, electric, power vent, direct vent, and even a commercial line), all located in the garage or a closet of a home, and all (in this distributor's experience) are installed or selected by the contractor.

- Water heaters cost from $\$ 250$ to $\$ 450$.

- Each water heater model is promoted by how efficient it is, how reliable it can be, and whether it is made locally.

- The manufacturer is usually the one who suggests new technology to distributors.

- A dual-service appliance, providing both water heating and dehumidification, would prove valuable, and consumers would be willing to pay a premium.

- Field tests results would have to show that it saves money, and benefits would have to outweigh cost. The unit has to be easily installed and the results must show minimal maintenance. The dehumidification level must be easily controllable.

\section{Retailers}

Three major retailers provided the following feedback:

- Areas where this appliance would work would be in the Northeast, the Midwest, and in Tennessee and other Southeast states (especially Florida), as well as states with warmer climates, such as California, Arizona, and Texas. It would be useful where humidity is high, including coastal areas. Basement areas are promising locations for this unit, particularly in Midwest cities like Chicago, Detroit, and Cleveland. There is definitely a market in East Tennessee, because a lot of people buy dehumidifiers, and everyone needs a water heater.

- Water heaters are installed under the house, in a utility room, in basements, and in garages. In Florida many people have them in closets inside homes, particularly in condos. Texas is another location where these appliances would be in the home (no basements). Basements would be the best place for this appliance because of mold and mildew problems.

- The best way to market this appliance would be to stress that it made the air cleaner or better and would offer health benefits. These comfort issues would help people feel better about the appliance and what it does for them. Another important audience is the elderly population.

- Cost seems a little on the high side, since a 50-gal water heater sells for around \$286 with a 12-year warranty and a dehumidifier sells for around $\$ 150$. People like self-cleaning units and are willing to pay $\$ 50$ more than standard for that feature. This product must have a warranty. Possibly this appliance would be a higher-end unit that would have a lifetime warranty. 
- Ease of repair would be important. The unit needs to be a "plug and play" system. When one system fails, you should not have to disconnect the entire system to repair it. Need to make sure the unit will accommodate retrofits nicely. They receive many complaints from plumbers in SE Florida. Overall, plumbers want easy installation without a lot of alteration. This product may be too big. Florida has under-the-counter units. Need to consider what type of breaker used by this system since houses cannot handle over 30 amps.

- Other potential issues for this product include lack of portability of the dehumidifier, ability of the product to draw the air through and dehumidify the air, the dominance of gas water heaters (since this is an electric appliance) in many regions, ability to meet all the code compliance for installation and drainage in basements, and noise level.

\section{Utilities}

Five Southeast utilities responded:

- Only two of the five promote water heater programs, the others have no interest in water heaters due to regional preference or company restrictions. As an example, North Carolina is 85 percent electric. With little competition from gas, there is no incentive to support water heaters. Three still offer incentives or rebates for energy efficient water heaters.

- The types of water heaters installed are propane, solar, electric, and gas. Water heaters are generally located in the basement or some unconditioned space like a garage. In Florida, they are mostly located in garages.

- All utilities indicate that the homeowner has the choice as to which brand, type, or model of water heater to install for retrofit units. Contractors/builders are involved with new-home unit selection.

- Consumers rarely call utilities to inquire about a unit's programs and features that are on the unit when problems arise.

- $\quad$ The price of water heaters ranges from \$200 (standard) to \$2000 (HPWH).

- They learn about new technology from technical assessment teams or research development groups.

- If the unit could be either gas or electric powered and be a heat pump water heater, then it would be of value to all the utilities. The homeowner, with these added benefits, would pay a premium for a dual-service appliance.

- A 5-percent reduction in energy costs would not be enough to prove valuable.

- The field tests would have to show amount of energy efficiency, speed in heating water, level of dehumidification, peak reduction, reliability, and cost-effectiveness.

\section{Developers/Property Managers - Apartments}

Responses from three property management companies from three different states (Washington, Texas, and Maryland) indicate:

- Electric water heaters are installed most frequently in apartment buildings, though gas water heaters are also installed. One company indicated that gas water heaters were installed if gas was the fuel source for cooking. 
- Gas and electricity service expenses are billed directly by the utility to the individual renters. Water usage is sometimes billed by the utility and sometimes by the property owner, depending on regional location.

- Water heaters are generally located in a separate utility closet, sometimes shared with the washer and dryer, within the apartment. These units are usually located next to a hallway, in the central part of the apartment. Water heaters can also be located in a utility shed outside of the building.

- Decisions for installing water heaters in newly constructed buildings are made by the building contractor. When a water heater needs to be replaced, the decision is made by either a company maintenance person/engineer or is referred back to the original building contractor for a recommendation. Factors considered in buying a replacement water heater include price, proven reliability, and longevity (10-20 years). Specific preferred materials features include stainless steel construction, glass lining, and brass fittings.

- Dehumidification is not considered an issue for buildings in Texas and Maryland. In Washington, general dehumidification is most needed in first-floor or subterranean apartments, where half the apartment is below ground. In addition, portable dehumidifiers are used to get rid of excess moisture caused by water overflows (sinks, toilets, bathtubs, etc.) and by leaks.

- A dual-service appliance, providing both water heating and dehumidification, would be of interest based on two factors: location in the country-particularly the Northeast (Washington) and the Southeast, and comparability in price to current life-cycle costs for water heater units (including price of water heater, various permits, and installation).

- The Washington-based property manager cited a \$158 average cost for water heater and electrical and city permits, which raise the total cost to $\$ 230$ - $\$ 240$ per unit. This does not include average installation costs.

- A dual-service, energy-efficient appliance offering 5-10\% cost savings would offer no benefit to the property manager because residents pay electric or gas bills directly to utilities. If there is an on-site laundry facility, there might be some benefit because the property manager would incur the cost of hot water supplied to the washing machines.

- Some properties owned by these companies with basements and large crawl spaces would benefit from dehumidification offered by a dual-service water heater. In the United States, more than $60 \%$ of basement homes have moisture problems. Notable areas were the Southeast (particularly Florida); Houston, Texas; and Washington (particularly in subterranean apartments or those with concrete foundation).

\section{Developers/Property Managers - Commercial}

Managers from five commercial facilities (hotels, hospitals, and assisted living) responded:

- All facilities have laundry operations with dedicated hot water. The water heating units are gas, electric, or steam. Only two facilities indicated heat and humidity problems associated with laundry facilities. Those with heat and humidity problems indicated that the unit could be of value if it were sold at a competitive price and if it substantially reduced energy costs.

\section{Energy Saving Advocate Organizations}

Three organizations that support energy-efficient technologies and practices responded: 
- Energy efficient and cost-effective products are supported. Specific technologies mentioned are heatpump, solar-powered, and condensing gas water heaters. Performance is important, and Energy Star® products are endorsed. One organization uses a committee to review different programs involving gas and electric water heaters.

- Location of the water heater in a home varies by region of the country and type of construction. In the Southeast, they are usually in the basement; in the Southwest, a utility space. They can also be located in attics and garages. In North Carolina, one-third of the homes are manufactured (water heaters are located in the homes). In homes with electric only they are usually in basements or crawl spaces; for homes with gas connections, garages.

- Decisions about purchase and replacement of an existing water heater are made by the homeowner and plumber.

- Many brands of water heaters within a price range of $\$ 250$ to $\$ 1500$ are being installed in homes. Water heater promotion used to include a web-based list, but now only provides general recommendations.

- Dehumidification is most needed in the Southeast and in coastal areas.

- Interest in a dual-service appliance varies. It might be of value if it provides benefits of air quality and comfort to the homeowner. Value of a dual-service appliance based on energy savings would only be of interest if there was a good cost-benefit ratio.

- $\quad$ Field tests of a new dual-service appliance would need to include energy savings, reliability, customer satisfaction, volume of water provided, cost-benefit, and how water from dehumidification is handled.

- Homes in coastal areas and manufactured homes would benefit most from this type of appliance.

- For manufactured home use, the tank must be kept at the 40- to 50-gallon size; also, understanding about how this device would work in winter is important.

\section{Other Organizations}

Three homebuilding/contractor associations indicated:

- All have committees that deal with electrical technologies, but the associations do not deal directly with residential water heating issues.

- Water heaters are installed mostly in the basement, if not there, then somewhere cool and out of the way.

- The contractor decides where and which kind of water heater to install. The homeowner decides what features he/she would like on the tank.

- There are three types of water heaters installed: gas, electric, and tankless.

- Consumers like a water heater's benefits and when they can decide which features to add.

- Water heaters are averaging around $\$ 200$.

- Both associations have companies, like A.O. Smith, that would ask them to research a certain or new technology.

- Only if the dual service unit could be controlled would the unit prove valuable, and if it interests the consumer, they would pay a premium. 
- 5 to 10 percent energy efficiency is barely enough to prove valuable.

- The field test should include how the unit stands up against other commercial brands, how easy it is to install, and how energy efficient it is.

\section{End- Use Consumers}

Three potential consumers of water heaters provided us with feedback:

- All have electric water heaters. The location of the water heater is in the basement, utility room, and laundry room.

- In deciding to purchase a water heater, respondents indicated the following possibilities: read about alternatives, consult with a plumber, use the EnergyGuide, consult with an appliance retailer/salesperson, consider the size and warranty, talk with neighbors, purchase from an appliance store.

- Two respondents do not own dehumidifiers. The respondent who does keeps it in the garage and seldom uses it (unless water is spilled on the floor). In deciding to purchase a dehumidifier, respondents indicated that they would compare alternatives, rely on a salesperson, or purchase one from an appliance store.

- In considering the value of replacing a current water heater with a dual-service water heating dehumidifier appliance, respondents indicated that this was not of value because of water heater location or lack of the need to dehumidify.

- In considering the added value of a dual-appliance to reduce electricity costs by 5 to 10 percent, respondents indicated that it could be of value if comparable in cost to standard water heater and if needed, a dehumidifier.

\begin{tabular}{|l|l|}
\hline \multicolumn{2}{|c|}{ Key Contacts For Dehumidifying Water Heater Discussions } \\
\hline \multicolumn{2}{|c|}{ Builders } \\
\hline Bell Development & $\begin{array}{l}\text { 423.266.1252 } \\
\text { www.belldevelopment.net/index.htm }\end{array}$ \\
\hline Centex Homes & $\begin{array}{l}919-781-1952 \\
\text { www.thejonescompanyhomes.com/Raleigh/ }\end{array}$ \\
\hline Mike Stevens Homes & $\begin{array}{l}865-450-9790 \\
\text { mksteven@bellsouth.net }\end{array}$ \\
\hline Oakwood & $\begin{array}{l}336-664-2400 \\
\text { www.0akwood.com }\end{array}$ \\
\hline Clayton Homes & $\begin{array}{l}\text { 865.380.3000 } \\
\text { gavinm@clayton.net }\end{array}$ \\
\hline \multicolumn{1}{|c|}{ Residential Property Managers/ Developers } \\
\hline Walden Company & $\begin{array}{l}972-788-0510 \\
\text { http://biz.yahoo.com/ic/41/41990.html }\end{array}$ \\
\hline The Shelter Group & $\begin{array}{l}\text { 410-962-0595 } \\
\text { www.thesheltergroup.com/ }\end{array}$ \\
\hline Pinnacle Realty Company & $\begin{array}{l}253-297-1962 \\
\text { www.pinnaclerealty.com/ }\end{array}$ \\
\hline & Com mercial Building Managers \\
\hline UNC Hospitals & $919-966-4131$ \\
\hline
\end{tabular}




\begin{tabular}{|c|c|}
\hline \multicolumn{2}{|c|}{ Key Contacts For Dehumidifying Water Heater Discussions } \\
\hline & www.unchealthcare.org \\
\hline Shepard's Grove Assisted Living & $\begin{array}{l}\text { 252-243-8440 } \\
\text { www.wilson-nc.com }\end{array}$ \\
\hline Crystal Coast Resort & $\begin{array}{l}\text { 252-726-2544 } \\
\text { www.nccoastchamber.com/crystalcoastinn }\end{array}$ \\
\hline Roanoke-Chowan Hospital & $\begin{array}{l}\text { 252-209-3170 } \\
\text { www.uhseast.com/body.cfm?id=93 }\end{array}$ \\
\hline Best Western Statesville Inn & $\begin{array}{l}\text { 1-800-359-4827 } \\
\text { www.statesville.nc.usa.freehotelguide.com/Best-Western- } \\
\text { Statesville-Inn.html } \\
\end{array}$ \\
\hline \multicolumn{2}{|r|}{ Utilities } \\
\hline Progress Energy & $\begin{array}{l}\text { 919-508-5672 } \\
\text { hal.lowrance@pgnmail.com }\end{array}$ \\
\hline NC Utilities & $\begin{array}{l}\text { Commission919-733-2267 } \\
\text { James.mchlawhorn@ncmail.net }\end{array}$ \\
\hline NYSERDA & $\begin{array}{l}\text { 518-862-1090 } \\
\text { wip@nyserda.org }\end{array}$ \\
\hline Tampa Electric & $\begin{array}{l}\text { 407-228-4111 } \\
\text { jecurrier@tecoenergy.com }\end{array}$ \\
\hline Florida Power and Light & $\begin{array}{l}\text { 407-942-9304 } \\
\text { www.fpl.com }\end{array}$ \\
\hline \multicolumn{2}{|r|}{ Advocates } \\
\hline $\begin{array}{l}\text { Consortium for Energy Efficiency } \\
\text { (CEE) }\end{array}$ & $\begin{array}{l}\text { 617-589-3949 } \\
\text { sjones@ceel.org }\end{array}$ \\
\hline North Carolina Energy Office & $\begin{array}{l}\text { 919-733-1901 } \\
\text { Russell.Duncan@ncmail.net }\end{array}$ \\
\hline $\begin{array}{l}\text { American Council for an Energy } \\
\text { Efficiency Economy (ACEEE) }\end{array}$ & $\begin{array}{l}\text { 202-429-8873 } \\
\text { www.aceee.govl }\end{array}$ \\
\hline \multicolumn{2}{|r|}{ Contractors } \\
\hline Brogdon Plumbing & $\begin{array}{l}\text { 865-544-0521 } \\
\text { http://phonebook.superpages.com/yellowpages/C- } \\
\text { Plumbing+Contractors/S-TN/T-Knoxville/PA-1/PB-30/PP-N/ }\end{array}$ \\
\hline Scott's Plumbing & 865-687-2686, sbr@scottsplumbing.net \\
\hline Ferguson Plumbing & 757-874-7400, ghram.ferguson@ferguson.com \\
\hline A to Z Discount Plumbing & $\begin{array}{l}\text { 919-872-3884, } \\
\text { http://phonebook.superpages.com/yellowpages/CP- } \\
\text { Construction+\&+Contractors\%5EPlumbing/S-NC/T-Raleigh/ }\end{array}$ \\
\hline \multicolumn{2}{|r|}{ Retailers } \\
\hline Sears & 615-792-6338, bcassidy@hotwater.com \\
\hline Lowe's & 865-690-9770, www.lowes.com \\
\hline Home Depot & 800-733-3768, www.homedepot.com \\
\hline \multicolumn{2}{|r|}{ Distributors } \\
\hline
\end{tabular}




\begin{tabular}{|c|c|}
\hline \multicolumn{2}{|c|}{ Key Contacts For Dehumidifying Water Heater Discussions } \\
\hline Modern Supply & 865-966-4567, pacer@modernsupplyco.com \\
\hline \multicolumn{2}{|r|}{ Consumers } \\
\hline $\begin{array}{l}\text { End-Use Consumers in Canton, } \\
\text { NC; Atlanta, GA; Seattle, WA }\end{array}$ & \\
\hline \multicolumn{2}{|r|}{ Others } \\
\hline $\begin{array}{l}\text { National Association of Home } \\
\text { Builders (NAHB); }\end{array}$ & $\begin{array}{l}\text { 703-907-5853 } \\
\text { ehudson@nahbrc.org }\end{array}$ \\
\hline $\begin{array}{l}\text { Home Builders Association of } \\
\text { Southern Tennessee }\end{array}$ & $\begin{array}{l}\text { 423-240-5978 } \\
\text { jbell.hbast@comcast.net }\end{array}$ \\
\hline $\begin{array}{l}\text { National Rural Electric Cooperative } \\
\text { Association (NRECA), }\end{array}$ & $\begin{array}{l}\text { 703-907-5853, } \\
\text { bob.gibson@nreca.coop }\end{array}$ \\
\hline
\end{tabular}

${ }^{a}$ AHAM's Dehumidifier Certification Program certifies dehumidifiers based on water removal capacity. It is expressed in pints per 24 hours at $80^{\circ} \mathrm{F}$ and 60 percent relative humidity. Dehumidifiers are tested under the ANSI/AHAM DH-1 Standard. Dehumidifiers (Current as of April 5, 2004) Brand names listed in AHAM's Dehumidifier Certification Program include Friedrich Air Conditioning Co., GE Appliances, LG Electronics, Inc., Oasis Corporation, W.C. Wood Company, LTD

${ }^{b}$ (www.ari.org) ARI is the trade association representing manufacturers of more than 90 percent of North American produced central air-conditioning and commercial refrigeration equipment. There is a Dehumidifier section of ARI which is chaired by Keith Coursin, from Desert Aire. The Dehumidifiers Section recently approved developing a rating method for dehumidification equipment integrated into a chilled water supply of either an absorption or vapor compression chiller

${ }^{c}$ Professional engineering society whose goal is to advance the arts and sciences of heating, ventilation, air conditioning and refrigeration and related human factors to serve the evolving needs of the public and ASHRAE. 


$$
\text { D-10 }
$$


ORNL/TM-2004/159

\section{INTERNAL DISTRIBUTION}
B. G. Ashdown
D. K. Jamison
E. Baskin
M. V. Lapsa
V. D. Baxter
R. L. Linkous
G. D. Boudreau
P. M. Love
M. A. Brown
V. C. Mei
J. E. Christian
T. L. Payne
W. G. Craddick
R. D. Quinn
E. C. Fox
M. M. Sherrod
D. J. Hill
F. Southworth
P. J. Hughes
Central Research Library
ORNL Laboratory Records-RC

\section{EXTERNAL DISTRIBUTION}
A.K. Ball Western Carolina University, Cullowhee, NC, ballaaron@wcu.edu
J. Dion, U. S. Department of Energy, Washington, DC, jerry.dion@ee.doe.gov
D. D. Dunlap Western Carolina University, Cullowhee, NC, ddunlap@wcu.edu
C. W. Ferguson Western Carolina University, Cullowhee, NC, cferguson@wcu.edu
R. Goodale, Institute at Biltmore, Asheville, NC, rgoodale@nc.rr.com
J.A. Laitner, U.S. Environmental Protection Agency, Washington, DC, Laitner.Skip@epamail.epa.gov
M.J. McCabe, U. S. Department of Energy, Washington, DC, Michael.mccabe@ee.doe.gov
F. Miceli, AB Technical Community College, Asheville, NC fmiceli@abtech.edu
R.L. Orrison, U. S. Department of Energy, Washington, DC, Richard.Orrison@ee.doe.gov
J.E. Rannels, U. S. Department of Energy, Washington, DC, james.rannels@hq.doe.gov
C. St. John, Clemson University, Clemson, SC, scaron@clemson.edu

A. Vohra, U. S. Department of Energy, Washington, DC, arun.vohra@ee.doe.gov 